Int. J. Dev. Biol. 61: 633-648 (2017)

doi: $10.1387 / \mathrm{ijdb} .170127 \mathrm{gs}$

\title{
From so simple a beginning - what amphioxus can teach us about placode evolution
}

\author{
GERHARD SCHLOSSER* \\ School of Natural Sciences, National University of Ireland Galway, Ireland
}

\begin{abstract}
Cranial placodes are an evolutionary novelty of vertebrates that give rise to many cranial sense organs and ganglia, as well as to the neurosecretory anterior pituitary. Although amphioxus does not have placodes, it shares with vertebrates several of the ectodermal patterning mechanisms and cell types that are important in placode development. Comparisons between amphioxus, vertebrates and other groups provide us with important insights into what the last common chordate ancestor probably looked like and allow us to propose a scenario for how placodes evolved by rewiring of gene regulatory networks. After reviewing ectodermal patterning and the cytodifferentiation of neurosecretory and sensory cells in amphioxus, this review will argue that the evolutionary origin of cranial placodes involved 1) the concentration of sensory and neurosecretory cell types in the head by linking their development to ancient cranial ectodermal patterning mechanisms; and 2) the formation of high density arrays of sensorineural precursors by intercalating a progenitor expansion module into the gene regulatory network driving differentiation of sensory or neurosecretory cells.
\end{abstract}

KEY WORDS: sensory cell, neurosecretory cell, ectodermal patterning, Hatschek's pit, chordate, evolutionary innovation

\section{Introduction}

Amphioxus (cephalochordates) are the least specialized among all living chordates and presumably retain most of the developmental pathways and adult characters that are also found in the extinct ancestors of chordates and vertebrates. This view is supported not only by many structural similarities but also by extensive parallels in early development between amphioxus and vertebrates, both of which rely heavily on long range inductive tissue interactions and morphogen gradients (Bertrand and Escriva, 2011, Holland, 2014). Tunicates (urochordates), in contrast, are a highly divergent and rapidly evolving group with a radically different adult body plan, which is established by deviant developmental mechanisms that depend mostly on cell lineage and local cell interactions (Lemaire, 2009).

However, recent molecularly based phylogenies have clearly shown that tunicates are the sister group of vertebrates whereas amphioxus are the sister group of the tunicate-vertebrate clade (Delsuc et al., 2006). The tunicate-vertebrate group is also known as "Olfactores", an unfortunate name because it suggests olfactory organs as a shared derived trait of this group, which is not supported by current evidence (see below).

The revised phylogenetic relationships among chordates indicate that the developmental and morphological similarities between amphioxus and vertebrates reflect shared primitive chordate traits (symplesiomorphies), many of which have been modified in the quickly evolving tunicate lineage but were preserved in the more slowly evolving stem lineages of amphioxus and the tunicatevertebrate clade. Therefore, amphioxus, despite being relegated to a more basal position within the chordates remains in many respects our best living model for the vertebrate ancestor. The last common ancestor of tunicates and vertebrates was in most respects more amphioxus-like than tunicate-like even though it will have displayed a few characters which are shared derived characters (synapomorphies) of the tunicate-vertebrate clade and will have missed those few characters that were uniquely derived in the amphioxus lineage (reviewed in (Bertrand and Escriva, 2011, Holland, 2014, Schubert et al., 2006a).

Here I will review, what insights amphioxus can provide regarding the evolutionary origin of cranial placodes (see also (Holland, 2005, Holland, 2009, Holland and Holland, 2001, Patthey et al., 2014, Schlosser, 2005, Schlosser, 2015, Schlosser et al., 2014). Cranial placodes are ectodermal thickenings that give rise to chemorecep-

Abbreviations used in this paper: GRN, gene regulatory network; RA, retinoic acid; TF, transcription factor.

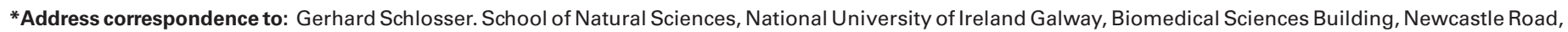
Galway, Ireland.Tel: 00353-91-495978. Fax: 00353-91-494526. E-mail: gerhard.schlosser@nuigalway.ie
} 
tive (olfactory placode) and mechanoreceptive (otic and lateral line placodes) sense organs of the vertebrate head, to the lens of the eye (lens placode), to sensory neurons of the cranial ganglia (profundal/trigeminal, epibranchial, otic and lateral line placodes) and to neurosecretory (hormone producing) cells in the anterior pituitary (adenohypophyseal placode) and forebrain (GnRHcells derived from the olfactory placode) (reviewed in (Grocott et al., 2012, Saint-Jeannet and Moody, 2014, Schlosser, 2010). All of these placodes have a common embryonic origin from the pre-placodal ectoderm (PPE), a crescent shaped region of ectoderm surrounding the anterior neural plate and neural crest (Fig. 1) defined by the expression of Six1/2 transcription factors and their cofactors of the Eya family.

Cranial placodes are one of two embryonic tissues that originated in the vertebrate lineage and are not found in other chordates; the second tissue is the neural crest which also contributes sensory neurons to the peripheral nervous system as well as pigment cells, glial cells, some gland and muscle cells and some cranial cartilage and bone. Together, cranial placodes and neural crest form many of the evolutionary novelties of the vertebrate head - the "New Head" of Northcutt and Gans (1983) - which were acquired when stem vertebrates diverged from their filter-feeding last common ancestor with the tunicates and adopted a more active and ultimately predatory life-style (Northcutt and Gans, 1983).

Cranial placodes are considered evolutionary innovations of vertebrates because they are not homologous to any structures outside the vertebrates. However, like other evolutionary innovations, cranial placodes did not evolve from scratch but by tinkering with pre-existing components: old genes were rewired to form new gene regulatory networks (GRN) and this led to pre-existing cell types being redeployed in new developmental contexts (Arendt et al., 2016, Schlosser, 2015). Based on comparisons between amphioxus, tunicates and vertebrates, I will argue in this review, that the evolutionary origin of cranial placodes in particular involved 1) the concentration of sensory and neurosecretory cell types in the head by linking their development to ancient cranial ectodermal patterning mechanisms; and 2) the formation of high density arrays of sensorineural precursors by intercalating a progenitor expansion module into the GRN driving differentiation of sensory or neurosecretory cells. Before I discuss this evolutionary scenario further in the last section of this review, I will first review ectodermal patterning mechanisms and the development of neurosecretory and sensory cells in amphioxus compared to vertebrates.

\section{Ectodermal patterning}

In amphioxus, different ectodermal territories along the dorsoventral and anteroposterior axis are specified in response to gradients of signalling molecules similar to vertebrates but different from tunicates. These signalling molecules act as morphogens which activate different transcription factors (TFs) at different concentration thresholds. The partly overlapping domains of TF expression along the dorsoventral and anteroposterior axis then in a combinatorial fashion map out a grid of regulatory states allowing to switch on distinct differentiation gene batteries at different positions (Peter and Davidson, 2015).

\section{Dorsoventral patterning}

Along the dorsoventral axis, a BMP gradient with high BMP levels ventrally and low BMP levels dorsally leads to induction of the neural plate dorsally and epidermis ventrally.

As in vertebrates, BMP2/4 in amphioxus is expressed throughout the ectoderm in the blastula (Yu et al., 2008, Yu et al., 2007). A BMP activity gradient then appears to be established during gastrulation by BMP inhibitors such as chordin secreted from the dorsal blastopore lip, which sequester BMP and prevent binding to its receptor on the dorsal side (Kozmikova et al., 2013, Yu et al., 2007). The dorsal side in amphioxus is, thus, positioned at the low end of a BMP gradient similar to vertebrates but opposite to the situation in protostomes. Hemichordates, which together with the echinoderms comprise the ambulacrarians, the sister group of chordates within the deuterostomes, have their dorsal side on the high-BMP side similar to protostomes (Lowe et al., 2006). This suggests that the dorsoventral axis was inverted in the chordate lineage (Arendt and Nubler-Jung, 1994, De Robertis and Sasai, 1996) resulting in the loss of the old mouth on the low-BMP (now dorsal) side and the formation of a new mouth on the high-BMP (now ventral) side.

In vertebrates, many TFs with widespread ectodermal expression are either directly or indirectly activated or repressed by BMP signalling. Consequently, they establish dorsally (SoxB1, Zic, Geminin) or ventrally (DIx3/5, Msx1, GATA2/3, AP2, Foxl1/3, and Vent1/2) restricted expression domains during gastrulation in response to the developing BMP gradient (reviewed in (Grocott et al., 2012, Saint-Jeannet and Moody, 2014, Schlosser, 2010). Whereas in amphioxus GATA1/2/3 is not expressed in the ectoderm (Zhang and Mao, 2009) and the expression of Geminin and Foxl1/3 is unknown, all other TFs show similarly restricted expression domains (Gostling and Shimeld, 2003, Holland et al., 2000, Holland et al., 1996, Kozmik et al., 2007, Kozmikova et al., 2013, Meulemans and Bronner-Fraser, 2002, Meulemans and Bronner-Fraser, 2007, Sharman et al., 1999, Yu et al., 2008, Yu et al., 2007). Moreover, amphioxus Vent1 and Vent2 were confirmed to be directly BMP responsive (Kozmikova et al., 2011) (Fig. 1). In addition, TFs Pax3/7 and Snail which define lateral neural plate identity in vertebrates are specifically expressed in the lateral neural plate in amphioxus (Holland et al., 1999, Langeland et al., 1998, Yu et al., 2008), where they are overlapping with the dorsalmost part of Vent and Msx. Taken together this suggests that general mechanisms of dorsoventral ectodermal patterning are conserved between amphioxus and vertebrates.

However, there are notable differences as well. Whereas in amphioxus Dlx extends dorsally into the anterior and lateral border region of the neural plate and AP2 is confined to the non-neural ectoderm (Holland et al., 1999, Yu et al., 2008), in vertebrates the situation is reversed with AP2 but not DIx3/5 extending into lateral neural ectoderm. More strikingly, none of the many other vertebrate TFs involved in defining lateral neural plate identity (Myc, Id, Hairy, Irx) or in specifying the neural crest (Twist, Ets, FoxD, SoxE) are specifically expressed in this domain in amphioxus (Kaltenbach et al., 2009a, Meulemans and Bronner-Fraser, 2004, Meulemans et al., 2003, Minguillon et al., 2003, Van Otterloo et al., 2012, Yasui et al., 1998, Yu et al., 2002c, Yu et al., 2008). Many of these genes probably were only recruited to the lateral neural plate with the evolution of a neural crest in vertebrates (Yu et al., 2008).

Furthermore, in contrast to vertebrates, in which Six1/2 and Eya genes become specifically induced in the dorsalmost part of the non-neural ectoderm forming the PPE during gastrulation, no such expression domain is observed in amphioxus and the nonneural ectoderm in amphioxus does not appear to be regionalized 
along the dorsoventral axis (Kozmik et al., 2007). Six1/2 and Eya in amphioxus are instead expressed in many scattered domains including parts of the brain, Hatschek's pit (see below), primary sensory cells and parts of endoderm and mesoderm (Kozmik et al., 2007). In vertebrates, several ventrally restricted TFs (DIx3/5, GATA2/3, AP2 and Foxl1/3) have been shown to act as competence factors, which are required in conjunction with BMP- and Wnt-inhibitors and FGF signals from the adjacent mesoderm and neural plate for induction of Six 1/2 and Eya in the dorsal non-neural ectoderm (Ahrens and Schlosser, 2005, Bhat et al., 2012, Kwon et al., 2010, Litsiou et al., 2005, Pieper et al., 2012). Similarly, in tunicates Six1/2 and Eya1 expression domains are established during gastrulation in dorsal non-neural ectoderm and require BMP inhibition (Abitua et al., 2015, Mazet et al., 2005) although nothing is known about the role of other signals or competence factors. Taken together, this suggests that the domain of Six1/2 and Eya expression in the dorsal non-neural ectoderm first evolved in the stem lineage of tunicates and vertebrates.

\section{Anteroposterior patterning}

Anteroposterior ectodermal patterning in amphioxus also shows some remarkable similarities to vertebrates (Fig. 1). In both groups, the establishment of distinct TF domains along the anteroposterior axis depends on gradients of Wnt and retinoic acid (RA) signalling with increasing Wnt and RA levels from rostral to caudal and a posteriorising role of Wnt and RA (Escriva et al., 2002, Holland, 2002, Holland, 2005, Schubert et al., 2004, Schubert etal., 2006b). FGF acts as an additional posteriorising signal in vertebrates but such a role has not been confirmed for amphioxus (Bertrand et al., 2011). The Wnt gradient is established by Wnt antagonists secreted from anterior endomesoderm, which prevent binding of Wnt to its receptor complex of frizzled and LRP5/6 proteins (Yu et al., 2007), while the RA gradient is established by anteriorly confined degradation of RA by the enzyme Cyp26 (Koop et al., 2014).

As in vertebrates, high levels of Wnt in the posterior directly activate multiple TFs, such as Gbx, Cdx and Irx (Beaster-Jones et al., 2008, Brooke et al., 1998, Castro et al., 2006b, Kaltenbach et al., 2009a) but repress FoxQ2 (a gene lost in several vertebrates) (Yu et al., 2003), while high levels of RA activate Hox genes (Koop etal., 2010, Onai et al., 2009, Pascual-Anaya et al., 2012, Schubert et al., 2004, Schubert et al., 2006b). Conversely, Otx, Six3/6 and Fezf become confined to anterior ectoderm (Irimia et al., 2010, Kozmik et al., 2007, Onai et al., 2009, Williams et al., 1996), presumably by cross-repressive interactions between Otx-Gbx, Six3/6-Irx and Fezf-Irx as shown in vertebrates. Finally, Pax6 and transitorily Pitx (further discussed below) in amphioxus are also expressed in the anteriormost non-neural ectoderm just rostral to the neural plate as in vertebrates (Boorman and Shimeld, 2002, Glardon et al., 1998, Yasui et al., 2000).

In addition to the TFs mentioned so far, many other TFs are involved in the subdivision of the PPE and the specification of distinct placodes along the anteroposterior axis in vertebrates (reviewed in (Grocott et al., 2012, Saint-Jeannet and Moody, 2014, Schlosser, 2010). For example, FoxG1, FoxE1and FoxE4, Dmrt and Anf are involved (together with Six3/6, Pax6 and Pitx) in the specification of anterior (adenohypophyseal, olfactory, lens) placodes, Pax3/7
Amphioxus

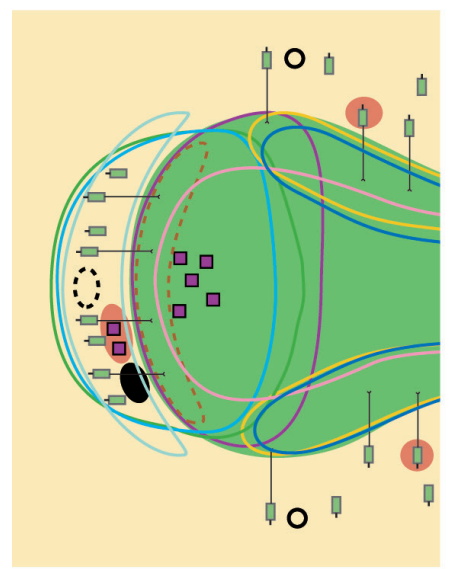

I primary sensory cells

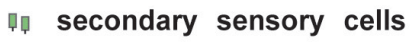
sensory neurons

$\square$ neurosecretory cells

o pharyngeal pouch

mouth
Tunicates

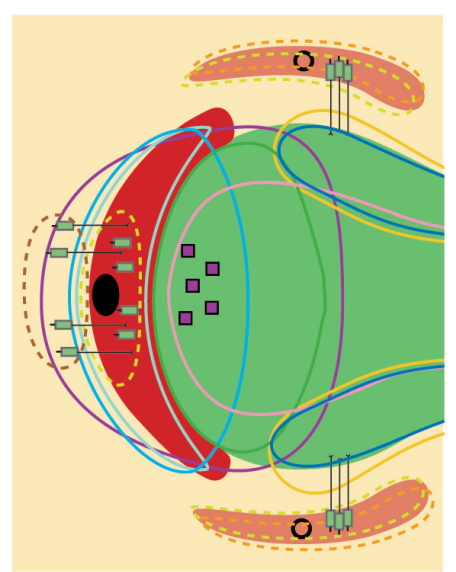

Vertebrates

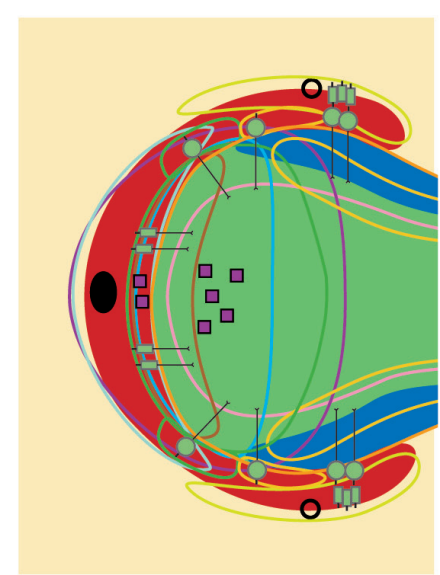

Fig. 1. Schematic overview of transcription factor domains and distribution of neurosecretory and sensory cells in ectoderm of chordate embryos. Epidermis is shown in yellow and neural plate in green. Domains of Six $1 / 2$ and Eya expression (including the preplacodal ectoderm in vertebrates) are depicted in red. Pale red domains in amphioxus (Hatschek's pitand sensory cells) and tunicates (atrial siphon primordia) indicate expression domains only established at later developmental stages. Neural crest (expressing a number of transcription factors) is shown in blue, while domains of Snail1/2 expression in tunicates and amphioxus are shown in blue outlines. Colored outlines enclose domains of TF expression domains except for Foxl in vertebrates and AP2, Dlx $3 / 5$, Vent $(A, V)$, GATA1/2/3 (T, V) Six1/2, Eya

Sox $2 / 3$

Snail 1/2, FoxD (V), SoxE (V), Twist (V), AP2 (V) Msx

Six3/6 (Irx complementary) Otx (Gbx complementary: A,V) FoxG

Foxl

Pitx

Pax6

Pax3/7

$\mathrm{Pax} 2 / 5 / 8$

Msx 1 in all taxa, which are expressed outside of the colored outlines. Hatched outlines indicate domains of TFexpression that are established at later developmentalstages. Hatched black circle in amphioxus indicates region corresponding to the tunicate and vertebrate mouth. Domains of Irx and Gbx expression are not shown but abut the domains of Six3/6 and Otx, respectively. Expression domains that are only present in some taxa are indicated by $A$, amphioxus; $T$, tunicates; $V$, vertebrates. Modified from (Schlosser et al., 2014). See text for details. 
in the specification of trigeminal placodes and $\mathrm{Pax} 2 / 5 / 8$ and SoxB1 in the specification of posterior (otic, lateral line, epibranchial) placodes. Whereas Dmrt and Anf have not yet been described for amphioxus, FoxG1, FoxE4, Pax3/7 and Pax2/5/8 are not expressed in amphioxus non-neural ectoderm (Holland et al., 1999, Kozmik et al., 1999, Kozmik et al., 2007, Toresson et al., 1998, Yu et al., $2002 b$ ) indicating that they acquired a role for anteroposterior ectodermal patterning only in the ancestors of vertebrates or the vertebrate-tunicate clade. One of the three SoxB1 paralogues in amphioxus, SoxB1c, is expressed in non-neural ectoderm, but its expression is confined to a few scattered cells in the middle of the embryo and around the mouth (Meulemans and Bronner-Fraser, 2007) unlike Sox2 and Sox3 in vertebrates, which are expressed throughout the posterior placodal region. SoxB1c is, therefore, more likely to play a role in processes like progenitor maintenance rather than in regional specification.

Thus, there is little evidence that amphioxus has any ectodermal territories sharing a transcriptional signature with the posterior or trigeminal placodes of vertebrates. However, many genes expressed in the posterior placodes of vertebrates (e.g. Pax2/5/8, Six1/2, Six4/5, Eya, SoxB1, Tbx1/10, Irx) are also co-expressed in the pharyngeal pouches of vertebrates and amphioxus. This has led to suggestions that a GRN from the pharyngeal pouches may have been recruited to pattern the posterior PPE (Schlosser, 2015). Since several of these genes (Pax2/5/8, Six1/2, Six4/5, Eya) are expressed in the ectoderm of the atrial siphon primordium of tunicates, which develop from posterior cranial ectoderm (Mazet et al., 2005, Wada et al., 1998), this may have happened already in the tunicate-vertebrate ancestor.

Only the anteriormost cranial non-neural ectoderm of amphioxus expresses a subset of TFs (Six3/6, Pax6, Pitx, Fezf) involved in specification of anterior placodes in vertebrates as well as Id proteins and a G-protein coupled receptor related to vertebrate odorant receptors (Meulemans et al., 2003, Satoh, 2005). This region of ectoderm may thus correspond to the ectodermal territory giving rise to the oral siphon primordium (stomodeum) in tunicates and the adenohypophyseal, olfactory and lens placodes in vertebrates. However, strong left-right asymmetries and the fusion of endomesodermal pouches with the ectoderm in this anterior region complicate the interpretation of homologies with vertebrates. I will, therefore, first briefly address these issues before returning to discuss its relation to the anterior placodes of vertebrates.

\section{Left-right patterning}

In contrast to vertebrates, amphioxus larvae show some remarkable left-right asymmetries affecting tissues derived from all germ layers particularly in the head region. While the mouth, Hatschek's pit and Hatschek's nephridium form on the left side, the endostyle (involved in food trapping) and the club shaped gland (which probably contributes to the secretion of pharyngeal mucus; (Holland et al., 2009)) form on the right side. Moreover, only the left series of gill slits develop in young larvae but they initially appear on the right side (Stokes and Holland, 1995). The proper right series of gill slits only forms much later at metamorphosis dorsal to the first series accompanied by a migration of the first series to the left side. Somites also form asymmetrically with left and right somites shifted by a half segment (Schubert et al., 2001). These morphological asymmetries are prefigured by the asymmetric expression of signalling molecules (Nodal, Lefty, Gdf1/3 in the left endomesoderm; cerberus in the right endomesoderm) and the TF Pitx (in the left endomesoderm and ectoderm) from neurula stage onwards (Boorman and Shimeld, 2002, Le Petillon et al., 2013, Onai et al., 2010, Soukup et al., 2015, Yasui et al., 2000, Yu et al., 2002a). In tunicates, a comparable left sided Pitx expression domain is driven by a different enhancer than the Pitx expression domain in the anteriormost non-neural ectoderm (see above) suggesting that these domains of expression are probably independently regulated (Christiaen etal., 2005, Yoshida and Saiga, 2008, Yoshida et al., 2012).

Additional signalling molecules (Dkk1/2/4) andTFs (Lxh3, FoxE4, Krox, FoxQ1, Nkx2.1, Hand) develop lateralized expression at later stages (Kaji etal., 2016, Soukup et al., 2015). Similar to vertebrates, nodal signalling in amphioxus was shown to be essential to set up these left right asymmetries. Pharmacological inhibition of nodal signalling leads to loss of left sided gene expression domains and structures (e.g. mouth and Hatschek's pit) and to mirror image duplication of those on the right side (Kaji et al., 2016, Soukup et al., 2015). This role of nodal signalling and its early downstream TF target Pitx in generating left-right asymmetries is also observed in tunicates, echinoderms and snails indicating that it reflects an old panbilaterian patterning mechanism (Boorman and Shimeld, 2002, Duboc et al., 2005, Grande and Patel, 2009a, Grande and Patel, 2009b, Molina et al., 2013, Yoshida and Saiga, 2008). It is currently unclear how left-right symmetry breaking is achieved in amphioxus but it has been suggested that leftwards fluid flow mediated by cilia on the archenteron roof, which leads to degradation of the nodal inhibitor cerberus on the left hand side may be involved as in Xenopus (Blum et al., 2014, Schweickert et al., 2010, Schweickert et al., 2007).

\section{The oral and preoral region of amphioxus}

With dorsoventral inversion at the base of chordates, the old mouth (on the low-BMP side) was obliterated and a new mouth formed on the new ventral side. In tunicates and vertebrates this mouth is located in a symmetric midventral position. In amphioxus larvae, however, the mouth opens to the left side. This asymmetric position of the amphioxus mouth together with the peculiarities of its embryonic development have long led to suggestions that the amphioxus mouth may not be homologous to the mouth of other chordates and may, for example, represent a modified left gill slit (reviewed in (Yasui and Kaji, 2008)). A recent study now supports the idea that the amphioxus mouth may instead be derived from the first left somite (Fig. 2 A, B) (Kaji et al., 2016). In amphioxus, the somites arise by enterocoely, i.e. by budding off the embryonic gut and contain small coelomic spaces (somitocoels). Kaji et al., now report that after the first anterior somite has separated from the endoderm, a small vesicle (termed the oral mesovesicle) buds off exclusively from the left anterior somite and fuses with the pharynx medially and the ectoderm laterally to form the amphioxus mouth (Fig. 2 A, B). The thickened caudal wall of the left first somite then develops into Hatschek's nephridium which forms a new duct connecting to the pharynx dorsal to the mouth opening. While these observations are supported by positional changes in gene expression domains (POU4, Pax3/7) and some semi-thin sections analysed by transmission electron microscopy, the reported BMP2/4 expression in the mouth could not be confirmed in a recent study (Yong et al., 2017). More detailed ultrastructural evidence including time series of serial TEM sections will be required to firmly establish 
the mode of mouth formation in amphioxus.

Another pair of outpocketings anterior to the first somites develop into Hatschek's left and right diverticula, which also have different fates. While the right diverticulum will expand to form the head coelom, the left diverticulum will fuse with the surface ectoderm to form the preoral pit, which gives rise to Hatschek's pit in the adult (Glardon et al., 1998, Hatschek, 1884, Kaji et al., 2016). For simplicity, I will use "Hatschek's pit" in this review to refer to both the larval (preoral pit) and adult structure. The differentiated cells in Hatschek's pit have presumably both exocrine and endocrine function (see below) and contact the ventral side of the brain in a manner reminiscent of the vertebrate pituitary (Gorbman et al., 1999). Hatschek's pit has, therefore, been often suggested to be homologous to the adenohypophyseal placode which gives rise to the anterior pituitary of vertebrates (reviewed in (Patthey et al., 2014, Schlosser, 2015). This idea was reinforced by the expression of TFs marking the adenohypophyseal and other anterior placodes such as Pit1, Pitx, Lhx, Islet, Pax6, Six3/6, Six1/2 and Eya in Hatschek's left diverticulum and pit (Candiani et al., 2008, Jackman et al., 2000, Kozmik et al., 2007, Wang et al., 2002) and of Pitx, Pax6 and Six3/6 in the adjacent ectoderm surrounding

A

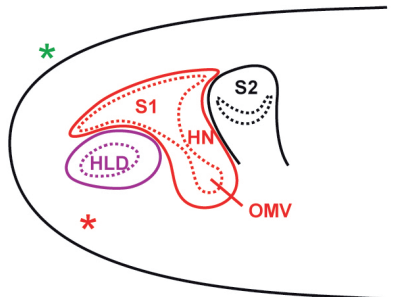

B

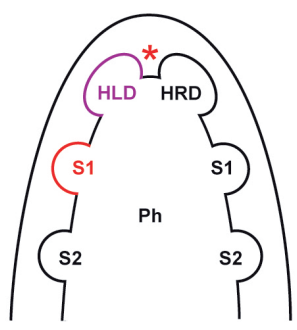

C

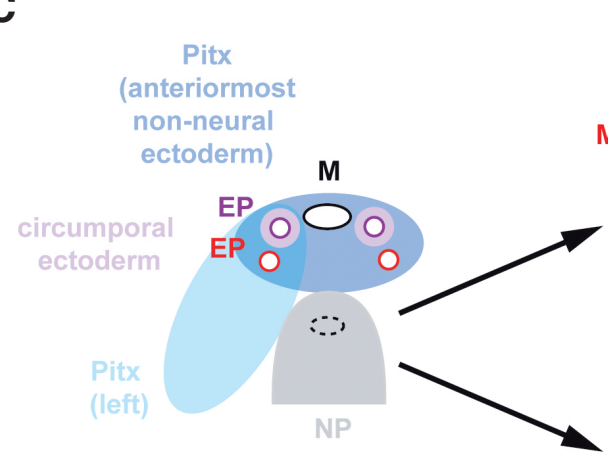

Chordate ancestor
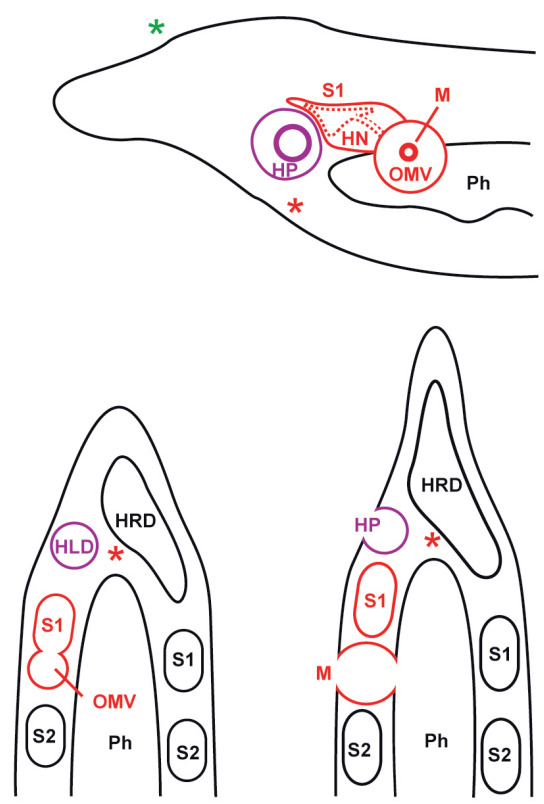

the opening of Hatschek's pit (Glardon et al., 1998, Kozmik et al., 2007, Yasui et al., 2000).

I will argue below that Hatschek's pit does not qualify as a homologue of the adenohypophyseal placode since it gives rise to very different cell types and lacks many other properties of proper placodes. Nevertheless, its position and TF signature suggest homology between the epithelial territory occupied by Hatschek's pit and the vertebrate adenohypophyseal placode. However, there are two difficulties with this interpretation: 1) the left-sided position of Hatschek's pit in front of a left-sided mouth versus the midline position of adenohypophyseal placode and mouth in vertebrates, and 2) the endomesodermal origin of Hatschek's pit versus the ectodermal origin of the adenohypophyseal placode. I will discuss these two problems in turn.

First, in contrast to vertebrates neither the amphioxus mouth nor Hatschek's pit appear to open into the Pitx expression domain in the anteriormost non-neural ectoderm immediately rostral to the neural plate but rather develop within the unilateral Pitx domain that develops slightly later on the left side in all germ layers (Yasui et al., 2000). Taken together with its different embryonic development (the details of which await further confirmation) this strongly suggests that the amphioxus mouth is not homologous to the vertebrate mouth. Instead it has been suggested to have evolved by elaboration of the pore that connects the anterior coelom (protocoel) in ambulacrarians to the outside and forms the hydropore in echinoderms and the proboscis pore in hemichordates (Kaji et al., 2016, Stach, 2002). The association of the pore/mouth with the excretory system in ambulacrarians and amphioxus also lend support to this proposal. However, the same pore has alternatively been suggested to have evolved into Hatschek's pit (Goodrich, 1917).

Although these two proposals appear to be in conflict, they are not necessarily mutually exclusive since

Fig. 2. Origin of amphioxus mouth and Hatschek's pit. (A) A recent study (Kaji et al., 2016) suggests that at early larval stages, an oral mesovesicle buds off from the left first somite (left panel), which later separates from the somite and connects to the pharynx and the outside forming the amphioxus mouth (right panel). The thickened posterior wall of the left first somite forms Hatschek's nephridium. (B) Schematic horizontal section through the pharyngeal region of amphioxus showing the formation of endomesodermal pouches giving rise to Hatschek's left and right diverticula and the somites. Hatschek's pit develops from Hatschek's left diverticulum. The mouth is here shown to develop from the oral mesovesicle budding off the first somite as proposed by (Kaji et al., 2016). Red asterisks in A and B indicate the approximate position, in which the mouth forms in vertebrates and tunicates, green asterisks in A indicate the position of the anterior neuropore. (C) Scenario for the evolution of mouth openings and endomesodermal pouches in chordates. Hatched oval indicates presumptive position of old mouth prior to dorsoventral inversion (obliterated in chordate ancestor). See text for details. Abbreviations: EP: endomesodermal pouch, HLD: Hatschek's left diverticulum, HRD: Hatschek's right diverticulum, HN: Hatschek's nephridium, HP: Hatschek's pit, M: mouth, NP: neural plate, OMV: oral mesovesicle, Ph: pharynx, S1: somite1, S2: somite2. Fig. 2A adapted from (Kaji et al., 2016). Fig. 2B adapted from (Soukup and Kozmik, 2016).
Tunicates \& Vertebrates
Amphioxus anterior placodal territory 
metameric structures such as the endomesodermal pouches can usually not be homologized on a one to one basis (e.g. the neck vertebrae of birds are homologous between species even though their numbers vary and it is not appropriate to homologize a particular vertebra between different species - such as neck vertebra number 3 between swans and hummingbirds).Thus, assuming that the chordate ancestor increased the number of endomesodermal pouches compared to the deuterostome ancestor, multiple pouches with protocoel-like characters may have been present, from which both the mouth and Hatschek's pit of amphioxus may have developed (Fig. 2C). Possibly, some of these pouches may have been retained as preotic head cavities in some vertebrate embryos (with different numbers in different groups) (reviewed in (Kuratani and Adachi, 2016).

Apart from these questions of homology, another unresolved question is whether the position of these pores in the chordate ancestor was bilaterally symmetrical or lateralized to the left side. In echinoderms there is a strongly asymmetrical development of the coelomic system with the protocoel forming a pore (which becomes the hydropore of the water-vascular system) on the left hand side (Peterson et al., 2000). However, nodal dependent Pitx expression in sea urchins is established on the right side (Duboc et al., 2005). Under the hypothesis of dorsoventral inversion at the base of chordates, the right side of echinoderms does correspond to the left side of chordates suggesting that the laterality of Pitx expression may have been preserved throughout deuterostomes but the position of coelomic pores may have changed.

In hemichordates, protocoel pores (proboscis pores) are present on both sides in some species (pterobranchs and some enteropneusts) or unilaterally (either left or right) in others (most enteropneusts) (Benito and Pardos, 1997). These pores open into a medial Pitx expressing domain of the dorsal ectoderm and no asymmetric Pitx expression domains have been described (Lowe et al., 2006). Recently, paired preoral outpocketings of the gut, each opening into the medial Pitx expression domain in the anteriormost non-neural ectoderm have also been described in some actinopterygian fishes (bichirs, gars) (Cerny et al., 2017). Taken together this suggests that Pitx which probably had an ancient role in left-right patterning has adopted an additional symmetric expression domain in anterior ectoderm possibly already in stem deuterostomes while losing its role in left-right patterning in hemichordates. It further suggests that the striking morphological left-right asymmetries in echinoderms and amphioxus are likely independently derived and the chordate ancestor may have been largely symmetrical with a midline mouth and paired endomesodermal pouches that opened into the anteriormost non-neural ectoderm (the anterior, symmetric Pitx domain) (Fig. 2C). Under this scenario, amphioxus has lost but tunicates and vertebrates retained - a midline mouth opening into the anterior Pitx domain and has elaborated some of its left endomesodermal pouches into a new mouth and Hatschek's pit, possibly under control of left-sided Pitx expression.

A second problem with the proposed comparison of Hatschek's pit with the adenohypophyseal placode is its partly endomesodermal origin. Moreover, even though the distinction between endomesodermally and ectodermally derived cells becomes indistinct once Hatschek's left diverticulum has fused with the ectoderm, the expression of many "adenohypophyseal" TFs (Pit1, Pitx, Lhx, Islet, Pax6, Six3/6, Six1/2, Eya) in Hatschek's pit appear to be confined predominantly or exclusively to its endomesodermally derived por- tion. In contrast, the adenohypophysis in all vertebrates is completely ectodermally derived. This includes the hagfish adenohypophysis, which was initially described to be of endomesodermal provenience (Gorbman, 1983) but has now been shown to develop from the ectoderm (Oisi et al., 2013).

There are, however, a number of examples where complex organs have shifted in evolution across boundaries created by epithelial fusion. For example, teeth and taste buds may originate from either ectodermally or endodermally derived parts of the mouth cavity depending on the species (Northcutt, 2004, Soukup et al., 2008, Stone et al., 1995). Similarly, the endomesodermal preoral gut diverticula recently described in some actinopterygian fishes (bichirs, gars, sturgeons) contribute to cranial adhesive organs, which are ectodermally derived in other vertebrates (Cerny et al., 2017). This suggests that regions of epithelial fusion may offer opportunities for TF domains to extend into topologically continuous epithelia derived from different germ layers (for example by maintaining responsiveness to local signalling pathways while losing responsiveness to germ layer specific TFs in cis-regulatory regions for genes encoding these TFs). TFs expressed in the endomesodermal part of Hatschek's diverticula may similarly have extended into adjacent circumporal ectoderm in the tunicate-vertebrate lineage followed by loss of the endomesodermal pouches and midline fusion of these ectodermal domains (Fig. 2C). Consequently, the oral/preoral ectoderm of the tunicate/vertebrate ancestor may have established its unique TF signature by the combination of TFs expressed in the anteriormost non-neural ectoderm of the chordate ancestor and those expressed in the adjacent endomesodermal pouches.

\section{Cell types}

\section{Neurosecretory cells}

There is a large diversity of neurosecretory cells in vertebrates originating from all germ layers. However, the subset of neurosecretory cells arising from some cranial placodes (adenohypophyseal and olfactory placodes) play a particularly central role (reviewed in (Schlosser, 2015). The adenohypophyseal placodes gives rise to all neurosecretory cells of the anterior pituitary, which regulates and coordinates all major endocrine systems of vertebrates. The olfactory placode produces migratory cells expressing gonadotropin releasing hormone $(\mathrm{GnRH})$ and other neuropeptides. A subpopulation of these migrates into the forebrain and settles in the hypothalamus where cells release $\mathrm{GnRH}$ to stimulate secretion of gonadotropic hormones from the adjacent adenohypophysis. Although the main population of neurosecretory cells producing $\mathrm{GnRH}$ or adenohypophyseal hormones originate from the cranial placodes, smaller populations of cells producing these hormones also develop from the brain and other tissues (reviewed in (Schlosser, 2005, Schlosser, 2015).

In jawed vertebrates, six different endocrine cell types develop in the adenohypophysis: melanotropes ( $\mathrm{MSH}$ - melanocyte stimulating hormone), corticotropes (ACTH - adrenocorticotropic hormone), thyrotropes (TSH - thyroid stimulating hormone), gonadotropes (FSH - follicle stimulating hormone and $\mathrm{LH}$-luteinizing hormone), lactotropes (PRL - prolactin) and somatotropes $(\mathrm{GH}$ - growth hormone) (reviewed in (Davis et al., 2013, Kelberman et al., 2009). The hormones produced by these cells fall into 3 classes: 1) peptide hormones ( $\mathrm{MSH}, \mathrm{ACTH})$, which are generated 
by proteolytic processing of larger precursor proteins, such as proopiomelanocortin (POMC); 2) dimeric glycoprotein hormones (TSH, FSH, LH), which are composed of a common alpha and a specific beta subunit; and 3) class I helical cytokines (GH, PRL) (Campbell et al., 2004). Only growth hormone but no prolactin producing cells are present in jawless vertebrates, which also have only one form of the glycoprotein beta subunits (GTH $\beta)$. This suggests that $\mathrm{PRL}$ and TSH/LH/FSH evolved by duplication of $\mathrm{GH}$ and $\mathrm{GTH} \beta$ genes, respectively in early gnathostomes and that only four cell types were present in the adenohypophysis of ancestral vertebrates (Kawauchi and Sower, 2006, Nozaki, 2008, Sower et al., 2009, Sower et al., 2006, Uchida et al., 2010).

The identity of different cell types in the adenohypophysis is established by combinations of TFs such as Tbx19 (Tpit) (melanotropes, corticotropes), NeuroD (melanotropes, corticotropes), GATA2 (thyrotropes, gonadotropes), SF-1 (gonadotropes), POU1f1 (Pit1) (somatotropes, lactotropes, thyrotropes), and others (reviewed in (Davis et al., 2013, Kelberman et al., 2009). We know less about how the identity of $\mathrm{GnRH}$ neurons is specified, although Msx, DIx and FoxG1 TFs appear to be involved (Garaffo et al., 2015, Givens et al., 2005).

In amphioxus, as in vertebrates, different types of neurosecretory cells have been identified, for example in the neural tube and Hatschek's pit. Most of our knowledge of these cells is based on immunostaining with antibodies raised against proteins from other animal groups (often vertebrates). However antibodies often recognize more than a single protein and cross-reactivity with amphioxus proteins may indicate binding to a protein that is not necessarily the orthologue of the vertebrate protein specifically recognized by the antibody. Therefore, data based on immunostaining have to be interpreted carefully and considered in combination with information on gene expression and genomics. Bearing these caveats in mind, what do we currently know about neurosecretory cells in amphioxus and their production of the 3 classes of hormones found in vertebrate placodes?

First, several cells immunoreactive for neuropeptides including FMRF amide, neuropeptideY, and $\mathrm{GnRH}$ were described in the neural tube and Hatschek's pit of amphioxus (Castro et al., 2003, Chang et al., 1984, Fang et al., 1999, Massari et al., 1999, Nozaki and Gorbman, 1992), but GnRH immunoreactivity in Hatschek's pit could not be confirmed in further studies (Castro et al., 2006a, Roch et al., 2014). The presence of many neuropeptides and their G-protein coupled receptors (GPCR) in amphioxus including one $\mathrm{GnRH}$-like peptide and $4 \mathrm{GnRH}$ receptors (two of those related to the vertebrate $\mathrm{GnRH}$ receptors) could be confirmed in the amphioxus genome (Holland et al., 2008, Mirabeau and Joly, 2013, Osugi et al., 2016, Putnam et al., 2008, Roch et al., 2014). However, none of the neuropeptides produced by the vertebrate adenohypophysis (MSH, ACTH) was found in either the amphioxus, ascidian or any other invertebrate genomes suggesting that these are vertebrate innovations (Campbell et al., 2004, Dehal et al., 2002, Holland et al., 2008, Putnam et al., 2008). Previous reports of POMC-related peptides in protostomes can possibly be explained by contamination with vertebrate tissues (Salzet et al., 1997, Stefano et al., 1999).

Second, cells immunoreactive for the vertebrate gonadotropins $\mathrm{FSH}$ and $\mathrm{LH}$ belonging to the heterodimeric glycoproteins were originally described in Hatschek's pit (Chang et al., 1984, Nozaki and Gorbman, 1992). However, it was subsequently shown that genes encoding the subunits of $\mathrm{FSH}$, LH or TSH were not present in either the amphioxus or ascidian genomes (Dehal et al., 2002, Holland et al., 2008, Putnam et al., 2008) indicating that these are novel vertebrate hormones. There are, however orthologs for the two subunits (GPA2, GBP5) of the related heterodimeric glycoprotein thyrostimulin from which the vertebrate $\mathrm{FSH} / \mathrm{LH} / \mathrm{TSH}$ most likely evolved and of their GPCRs in amphioxus (Dos Santos et al., 2009, Roch and Sherwood, 2014). Moreover, amphioxus GPA2 is transitorily expressed in Hatschek's left diverticulum (Dos Santos et al., 2009) suggesting that cells in Hatschek's pit may produce hormones of the heterodimeric glycoprotein class in addition to neuropeptides.

Third, and finally, no immunoreactivity for GH and PRL antibodies has been reported in amphioxus (Nozaki and Gorbman, 1992) and initially no class I helical cytokines including GH and PRL have been identified in amphioxus or ascidian genomes (Dehal et al., 2002, Putnam et al., 2008), although related hormones and their receptors were described in protostomes (Huising et al., 2006). However, a recent report describes a class I helical cytokine and an associated receptor from amphioxus, which may be related to $\mathrm{GH}$ in vertebrates (although bootstrap support is low and orthology remains unclear) and is widely expressed in the embryo including in Hatschek's pit (Li et al., 2014). This suggests that Hatschek's pit may also produce class I helical cytokines.

Taken together, currently only the $\mathrm{GnRH}$ producing cells in amphioxus are good candidates for neurosecretory cell types with homology to some of the specific, placodally derived neurosecretory cell types of vertebrates although nothing is presently known about the TFs underlying cytodifferentiation of these cells in amphioxus. In amphioxus, these cells are localized in the brain
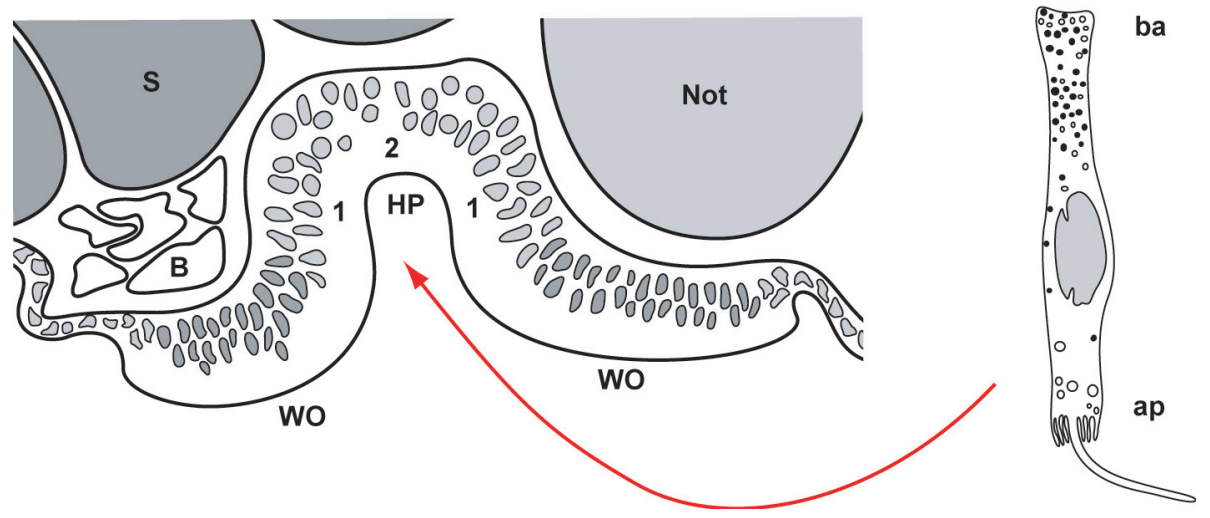

Fig. 3. Neurosecretory cells in Hatschek's pit of amphioxus. Cross-section through Hatschek's pit shown in left panel, single cell from Hatschek's pit in the right panel. All cells in Hatschek's pit are ciliated and have large vesicles on the apical side with putative exocrine function. In addition, some cells (particularly in region 1) contain numerous small vesicles with putative endocrine function and are located next to blood vessels. Abbreviations: ap: apical, B: blood vessels, ba: basal, HP: Hatschek's pit, Not: notochord, S: somite, WO: wheel organ. Left panel adapted from (Sahlin and Olsson, 1986), right panel adapted from (Welsch and Welsch, 1978). See text for details. 
and not in Hatschek's pit. All of the hormones produced in the vertebrate adenohypophysis (with possible exception of $\mathrm{GH}$ ) appear to be vertebrate innovations even though related hormones belonging to the same classes are found in Hatschek's pit. In addition, the TFs Pit1 and Islet, which play a role in specifying some adenohypophyseal cell types are expressed in Hatschek's pit (Candiani et al., 2008, Jackman et al., 2000). This suggests that Hatschek's pit does act as a neurosecretory organ although we currently know little about the precise complement of hormones it produces or their function.

An endocrine function for Hatschek's pit is also supported by ultrastructural evidence for small vesicles in the basal parts of many of the cells in the epithelium of Hatschek's pit, which are located next to blood spaces (Fig. 3) (Sahlin and Olsson, 1986, Tjoa and Welsch, 1974). Large vesicles in the apical part of some of these cells suggest that they also have an additional exocrine function and probably contribute to the production of mucus for trapping food particles similar to the cells of the adjacent wheel organ (Lacalli, 2007, Tjoa and Welsch, 1974) (Fig. 3). Apically, the cells of Hatschek's pit resemble sensory cells in bearing a cilium surrounded by microvilli (Fig. 3) but no evidence for synaptic vesicles or axonal processes could be found (Sahlin and Olsson, 1986, Tjoa and Welsch, 1974). A more recent study showed nerve fibers in the vicinity of Hatschek's pit but did not clarify whether there is any innervation of the pit itself (Kaji et al., 2001). It has therefore been suggested that these cells may control endocrine (e.g. reproductive) functions by directly releasing hormones into the circulation in response to environmental signals (Gorbman, 1995, Nozaki and Gorbman, 1992). Recently, neurosecretory cells originating from the anteriormost non-neural ectoderm have also been identified in ascidians. However, in contrast to amphioxus, these ascidian cells produce $\mathrm{GnRH}$ and $\mathrm{CNG}$ channels and have an axon indicating that they are proper neurons, which combine neuroendocrine and chemosensory functions (Abitua etal., 2015). It is currently unknown whether any other neuropeptides, glycoprotein hormones or class I helical cytokines are produced by cells in the anteriormost non-neural ectoderm in tunicates.

\section{Sensory cells}

The cranial placodes of vertebrates give rise to several different sensory cell types. Two main types of chemosensory cells, olfactory and vomeronasal receptor cells, are produced by the olfactory placode (Maier et al., 2014). Both cell types are primary sensory cells with axons that transmit the information to the brain and they carry cilia, microvilli or both. Olfactory receptor cells express one out of several hundred odorant receptors and activate cyclic nucleotide gated (CNG) ion channels, whereas vomeronasal receptor cells express the pheromone receptors VR1 and VR2 and activate transient receptor potential (TRP) channels (Elsaesser and Paysan, 2007, Kaupp, 2010). Odorant and pheromone receptors represent two different families of GPCRs, which are only found in chordates. The mechanosensory hair cells originate from the otic and lateral line placodes and mediate perception of sound, position in space and water movements. They have a bundle of microvilli arranged in a staircase like fashion next to a cilium and are activated by the mechanical opening of ion channels, when microvilli bend (Fritzsch et al., 2007). Hair cells are secondary sensory cells, i.e. they do not have an axon. Instead they release synaptic vesicles to activate somatosensory neurons derived from the same placodes, which transmit the information to the brain. Other somatosensory neurons derived from profundal and trigeminal placodes as well as viscerosensory neurons derived from epibranchial placodes have either free nerve endings or supply non-placodal sensory cells and mediate touch, temperature and pain sensation in the skin and viscera, respectively (reviewed in (Patthey et al., 2014, Schlosser, 2010).

Basic helix-loop-helix (bHLH) TFs of the Achaete-scute, Atonal and Neurogenin families play a central role in initiating differentiation and defining the identity of these various sensory cells in vertebrates, with Ascl1, Atoh1 and Neurog1/Neurog2 being required for the differentiation of olfactory receptor cells, hair cells and sensory neurons, respectively (reviewed in (Bertrand et al., 2002, Huang et al., 2014, Schlosser, 2006, Schlosser, 2010). Additional bHLH and homeodomain TFs, in particular COE, LIM (Islet1, Lhx2), Paired like (Phox2a, Phox2b), and POU4 domain (POU4f1/Brn3a, POU4f3/ Brn3c) TFs also contribute to the specification of cell type identity (reviewed in (Alsina et al., 2009, Fritzsch et al., 2007, Maier et al., 2014, Schlosser, 2006, Schlosser, 2010). TIx homeodomain TFs (TIx1, TIx3), which are widely expressed in placode and neural crest derived sensory neurons (Logan et al., 1998) have been implicated in promoting excitatory (glutamatergic) differentiation (Cheng et al., 2004).

Although our current understanding is far from complete, specific combinations of these TFs appear to be involved in conferring cell type identity to the different sensory and neuronal cell types derived from placodes including olfactory receptor neurons (Ascl1, Neurog1, Lhx2), hair cells (Atoh1, POU4f3 and the zinc finger protein Gfi1), somatosensory neurons (Neurog1, POU4f1, Islet1) and viscerosensory neurons (Neurog2, Phox2b) (reviewed in (Patthey et al., 2014, Schlosser, 2015). It should be noted, however, that cell types with the same transcriptional signatures and similar phenotypes also originate from the brain and other tissues, such as epidermally derived mechanoreceptive Merkel cells (Atoh1, POU4f3, Gfi1) and neural crest derived somatosensory cells of the proximal cranial and dorsal root ganglia (Neurog1, POU4f1, Islet1). Such "serial sister cells" (Arendt et al., 2016) demonstrate that the same cell type (or evolutionarily related cell types) can be produced by different tissues in development (Arendt et al., 2016, Schlosser, 2015).

In amphioxus, sensory cells with potential homology to the chemo- and mechanosensory cells of vertebrates are widely scattered throughout the non-neural ectoderm (reviewed in (Holland, 2005, Holland and Holland, 2001, Lacalli, 2004). Two major subtypes of epidermal sensory cells have been described. Type I sensory cells have a long cilium surrounded by microvilli and are (predominantly or exclusively) primary sensory cells, while type II sensory cells possess a short cilium surrounded by a peculiar collar covered with microvilli and appear to be secondary sensory cells (Baatrup, 1981, Lacalli and Hou, 1999, Schulte and Riehl, 1977, Stokes and Holland, 1995) (Fig. 4). Whereas type I cells originate in early embryos, type II cells only appear weeks later just prior to metamorphosis (Stokes and Holland, 1995).

Additional specialized sensory cell types have been described from particular regions, for example ventral pit cells (with recessed cilium, no microvilli) on the metapleural folds, oral spine cells (with cilium, no microvilli, no axon) surrounding the mouth opening (Fig. 4 ), and rostrally confined cells with ciliary spines or with recessed cilia in irregular pits (Lacalli, 2002, Lacalli et al., 1999, Lacalli and 
Hou, 1999, Stokes and Holland, 1995). There are also rostral epithelial cells without obvious specializations but which contain synaptic vesicles and are innervated (Lacalli, 2002). Finally small sensory organs, the corpuscles of de Quatrefages, composed of 1-4 sensory cells (with 2 cilia each) surrounded by up to 7 sheath cells, can be found in the rostral ectoderm (Baatrup, 1982) (Fig. 4). The cells forming the ciliated tufts of the rostral and oral papillae of amphioxus (Fig. 4) lack synaptic specializations and were, therefore, proposed to be more likely ciliary effectors than sensory cells (Lacalli et al., 1999).

Currently we do not know, which sensory modalities are mediated by each of these cells. Based on their morphology, corpuscles of de Quatrefages and oral spine cells are putative mechanoreceptors, while type I cells have proposed to be mechano- and/or chemoreceptors and type II cells chemoreceptors, but this has never been confirmed by physiological studies (Baatrup, 1982, Lacalli et al., 1999, Lacalli and Hou, 1999). Some of the rostral primary (type I) sensory cell have been shown to express a vertebrate type odorant receptor (Satoh, 2005) suggesting that these cells are indeed chemosensory. Around 50 genes encoding vertebrate type odorant receptors (but no vomeronasal receptors) have been identified in

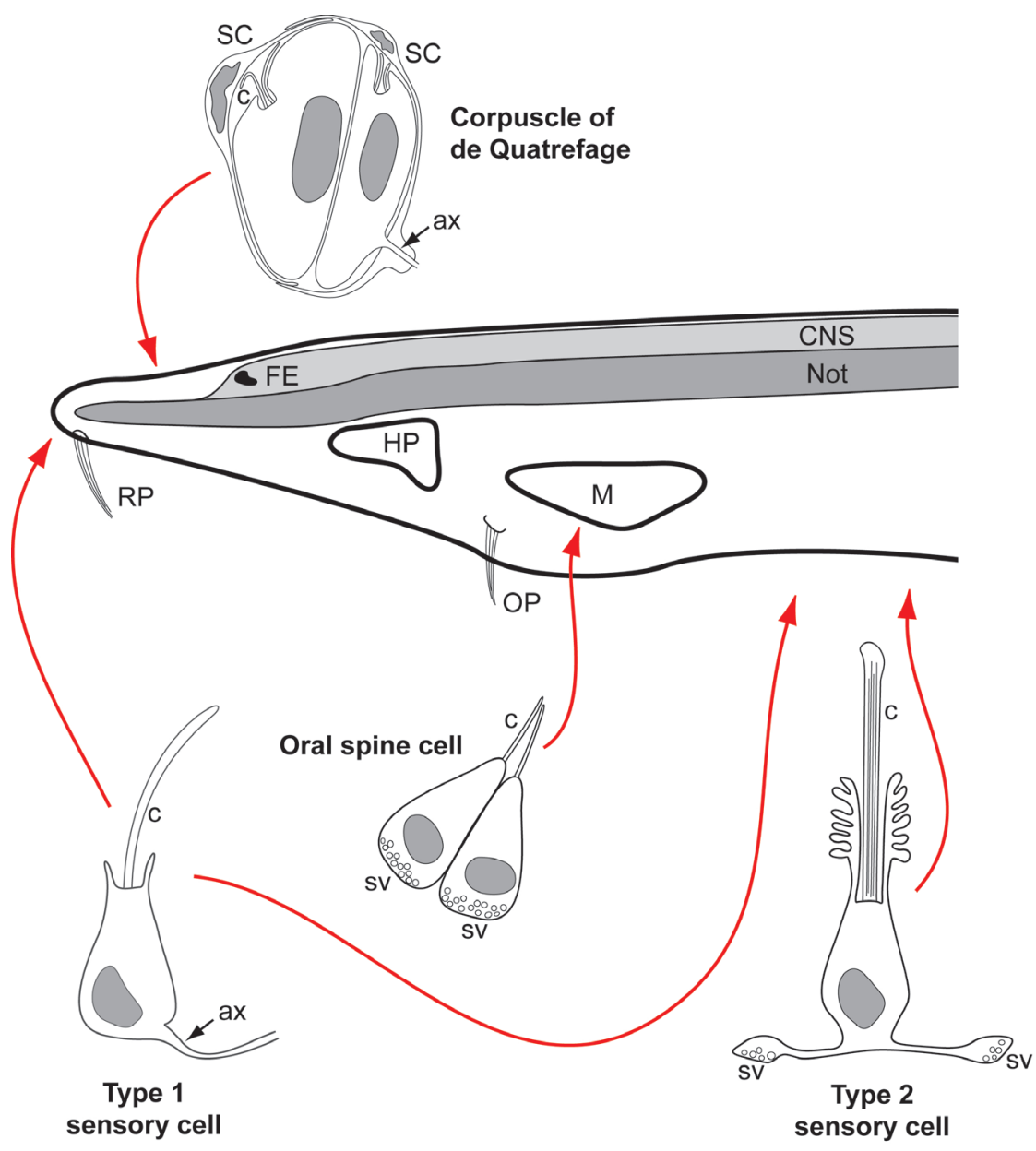

Fig. 4. A selection of sensory cells in amphioxus. Red arrows indicate locations of these cells in an amphioxus larva (left side of head region shown). Abbreviations: ax: axon, c: cilium, CNS: central nervous system, FE: frontal eye, HP: Hatschek's pit, M: mouth, Not: notochord, OP: oral papilla, RP: rostral papilla, SC: sheath cells, sv: synaptic vesicles. Adapted from (Baatrup, 1982, Lacalli, 2004, Lacalli et al., 1999). See text for details. the amphioxus genome representing an independent expansion of odorant GPCRs in the amphioxus lineage (Churcher and Taylor, 2009, Niimura, 2009). Whether the expression of these genes is confined to mutually exclusive subsets of rostral chemosensory neurons as in vertebrates remains to be investigated.

Many of the TFs involved in sensory and neuronal specification of vertebrates are also expressed in amphioxus sensory cells or subsets of them (although expression of amphioxus Atonal has not been described) (Fig. 5A). Rostral sensory cells of amphioxus develop in regions of the ectoderm, which express Neurogenin and POU4 (Candiani et al., 2006, Holland et al., 2000). POU4 is also expressed around the mouth, where oral spine cells develop and in a large population of more caudal primary (presumably type I) neurons (Candiani et al., 2006). The latter have been shown to originate in the ventral ectoderm, where they delaminate and migrate dorsally before reinserting into the epidermis and differentiating into sensory neurons (Benito-Gutierrez et al., 2005b, Kaltenbach et al., 2009b) (Fig. 5B). Various subsets of these cells probably express TFs Ash, COE, Islet, POU4, TIx, SoxB1c, Six1/2, Six4/5, Eya as well as the panneuronal marker Hu/Elav and the Notch ligand Delta, which represses neuronal fates in adjacent cells via lateral inhibition (Benito-Gutierrez et al., 2005a, Candiani et al., 2006, Kaltenbach et al., 2009b, Kozmik et al., 2007, Lu et al., 2012, Mazet et al., 2004, Meulemans and Bronner-Fraser, 2007, Rasmussen et al., 2007, Satoh et al., 2001, Schubert et al., 2004). Which TFs are expressed in type II receptors and the neurons that innervate them is currently unknown due to their late development just prior to metamorphosis.

Since few double-labeling studies have been performed, we currently lack information, which of the TFs expressed in type I cells are indeed co-expressed in single cells. However, the distribution of cells expressing the different TFs in amphioxus indicates that there can be only partial overlap suggesting that the population of type I sensory cells is molecularly heterogeneous. The TF expression patterns also do not suggest a oneto-one correspondence of any of the amphioxus sensory cells with a particular vertebrate sensory cell type (Patthey et al., 2014).

\section{Evolution of placodes}

This survey of ectodermal patterning mechanisms and cell types in amphioxus reveals both similarities and differences to vertebrates. Comparison between the two groups together with insights from other deuterostomes allows us to make some tentative inferences about their last common ancestors, the ancestral chordates although alternative scenarios involving the convergent evolution or parallel reductions of structures cannot be ruled out. Similarities between the dorsoventral patterning mechanisms in amphioxus, vertebrates and hemichordates suggest that ancestral chordates probably used BMP-dependent dorsoventral patterning mechanisms to set up distinct TF expression 
domains in dorsal (neural: SoxB1, Zic) and ventral (non-neural: DIx3/5, Msx1, AP2, and Vent1/2) ectoderm.

However, the non-neural ectoderm was relatively homogeneous and Six $1 / 2$ and Eya were not expressed in its dorsalmost part. It probably gave rise only to scattered sensory cells throughout its extent without forming any high density arrays of sensory cells or neurons unlike the vertebrate PPE. Other TFs were expressed in a regionalized fashion along the anteroposterior axis in a Wnt and RA dependent way (with anterior expression of Otx, Six $3 / 6$ and Fezf and FoxQ2 and posterior expression of Gbx, Cdx, Irx). However, many other TFs involved in the distinction of different vertebrate placodes along the anteroposterior axis were probably not expressed in the ectoderm of the chordate ancestor. There may have been some left-right asymmetries governed by left sided nodal signalling and Pitx expression but the overall bodyplan was probably largely symmetrical with a midventral mouth flanked by bilaterally symmetrical endomesodermal pouches opening into a separate and symmetric Pitx domain in the anteriormost non-neural ectoderm.

The anteriormost of these pouches possibly opened to the outside to form a rostral neurosecretory organ, which may have helped to regulate various body functions by releasing different types of hormones (but neither $\mathrm{GnRH}$ nor any of the adenohypophyseal hormones of vertebrates) into the blood stream in response to environmental stimuli. Anteriorly positioned TFs (e.g. Six3/6, Pitx) together with TFs specifying neurosecretory cytodifferentiation (e.g. Pit1, Islet) may have cooperated to specify cells in this organ. Chemo- and mechanosensory cells of different types were probably scattered mostly as single cells throughout the surface of the ectoderm. Many of them were primary sensory cells, but secondary sensory cells that were innervated by sensory neurons were also present. Specification of these cells most likely involved some of the same bHLH and homeodomain TFs (e.g. Achaete-scute, Neurogenin and possibly Atonal, COE, LIM, POU4, Six1/2) that also play a role in the specification of placodal cells in vertebrates and some of the TFs expressed in a regionalized manner along the anteroposterior axis probably contributed to cell fate specification.

Thus, for some of the ectodermal territories and cell types of the chordate ancestors, corresponding (homologous) territories and cell types can be identified in vertebrates Beyond these similarities, however, two features of chordate ancestors as inferred from the comparison among living taxa were strikingly different from vertebrates: 1) neurosecretory cells in the rostral neurosecretory organ were possibly mostly endomesodermally derived and sensory cells were not confined to particular ectodermal territories; and 2)
Pitx, POU4, SoxB1C

TIx, POU4, Coe, (Ash, Six1/2, Eya, SoxB1c, Islet, ERR, Hox1, Hox3, Hox4) TF?

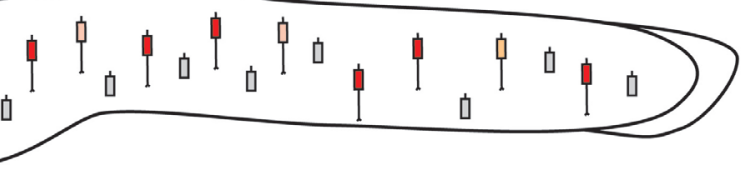

的 Corpuscles of de Quatrefage

Oral spine cells

[ Neurosecretory cells (Hatschek's pit)

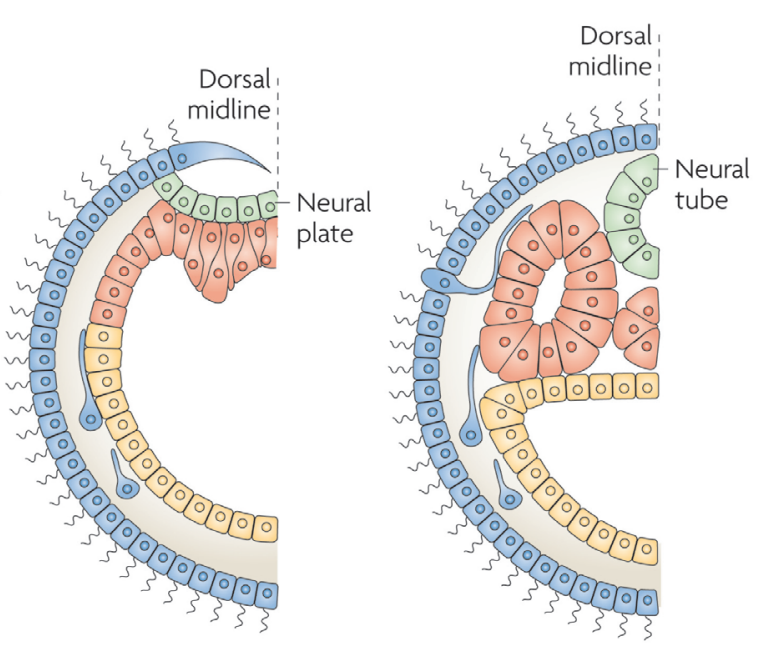

Ectoderm

(-) Mesoderm 0 Neural crest 0 Endoderm

Fig. 5. Distribution and origin of sensory cells in amphioxus. (A) Distribution of different types of sensory cells and their pattern of transcription factor (TF) expression is indicated. Type 1 senexpressed in subsets of sensory cells. The TFs expressed in type 2 sensory cells, which develop r, are currently not known. (B) Precursors of type 1 sensory cells delaminate from the ventral ectoderm, migrate dorsally and then reinsert into the ectoderm. (A) is adapted from Meulemans and Bronner-Fraser (2007). (B) was reprinted with permission from Macmillan Publishers Ltd: Nature Reviews Neuroscience (Holland, 2009).

most of the sensory cells probably developed as single cells rather than as part of sensory organs. The evolution of placodes as novel structures thus required changes in gene regulatory interactions 1) to concentrate neurosecretory and sensory cells in dorsal and anterior parts of the non-neural ectoderm by establishing new links between ectodermal patterning mechanisms and TFs driving cytodifferentiation and 2) to expand the population of sensory and neurosecretory progenitors prior to differentiation thereby allowing the formation of large, multicellular sense organs.

Based on the expression of Dlx and Msx and the origin of sensory cells throughout the non-neural ectoderm of amphioxus embryos, it has previously been suggested that possibly the entire non-neural ectoderm in the neurula stage of ancestral chordates was equivalent to the PPE of vertebrates, which became confined to the neural plate border region when the embryos increased in size in the vertebrate lineage (Holland, 2009). However, sensory 
cells scattered throughout the epidermis are found in many other invertebrates of various sizes; the non-neural ectoderm of amphioxus (and presumably of the ancestral chordates as well) does not give rise to high density arrays of sensory cells and neurons because there is no expansion of sensorineural progenitors prior to differentiation unlike in vertebrate placodes; and Dlx and Msx expression domains in vertebrates are not confined to the PPE but extend into the prospective epidermis in early embryos (Schlosser, 2015, Schlosser et al., 2014). Taken together this suggests that the non-neural ectoderm in the last common ancestor of chordates evolved into epidermis but does not support its homology to the PPE or placodes.

Due to their panplacodal expression in vertebrates and their essential dual role for both progenitor proliferation and cytodifferentiation in all vertebrate placodes, genes encoding Six $1 / 2$ (and Six4/5) TFs and their Eya cofactors have been proposed to play a central role for placode development and rewiring in the GRN up- and downstream of these genes has been suggested to account for many of the evolutionarily novel features of placodes
(Schlosser et al., 2014) (Fig. 6).

The role of these genes for sensory differentiation in many bilaterians together with their expression in isolated sensory cells in amphioxus suggests that they may have retained an ancient role in sensory differentiation in chordate ancestors (Schlosser, 2015, Schlosser et al., 2014). Recruitment of Six1/2 and Eya expression to the dorsalmost non-neural ectoderm may then have happened in the ancestors of tunicates and vertebrates by changes in their cis-regulatory sequences that made their expression dependent on dorsal and anterior signals (e.g. FGF and BMP-inhibitors, Wnt-inhibitors) and non-neural TFs acting as competence factors (e.g. Dlx, Foxl1/3, GATA1/2/3, AP2). Comparisons with tunicates suggest that in the tunicate-vertebrate ancestor Six1/2 and Eya were coexpressed with Six3/6, Pitx, and some additional TFs such as Dmrt and FoxG (which play a role for the development of an anterior group of placodes in vertebrates) anteriorly, whereas Six 1/2 and Eya1 were coexpressed with Pax2/5/8 and Foxl (which are involved in the specification of a posterior group of placodes in vertebrates) further posteriorly. These anterior and posterior proto-

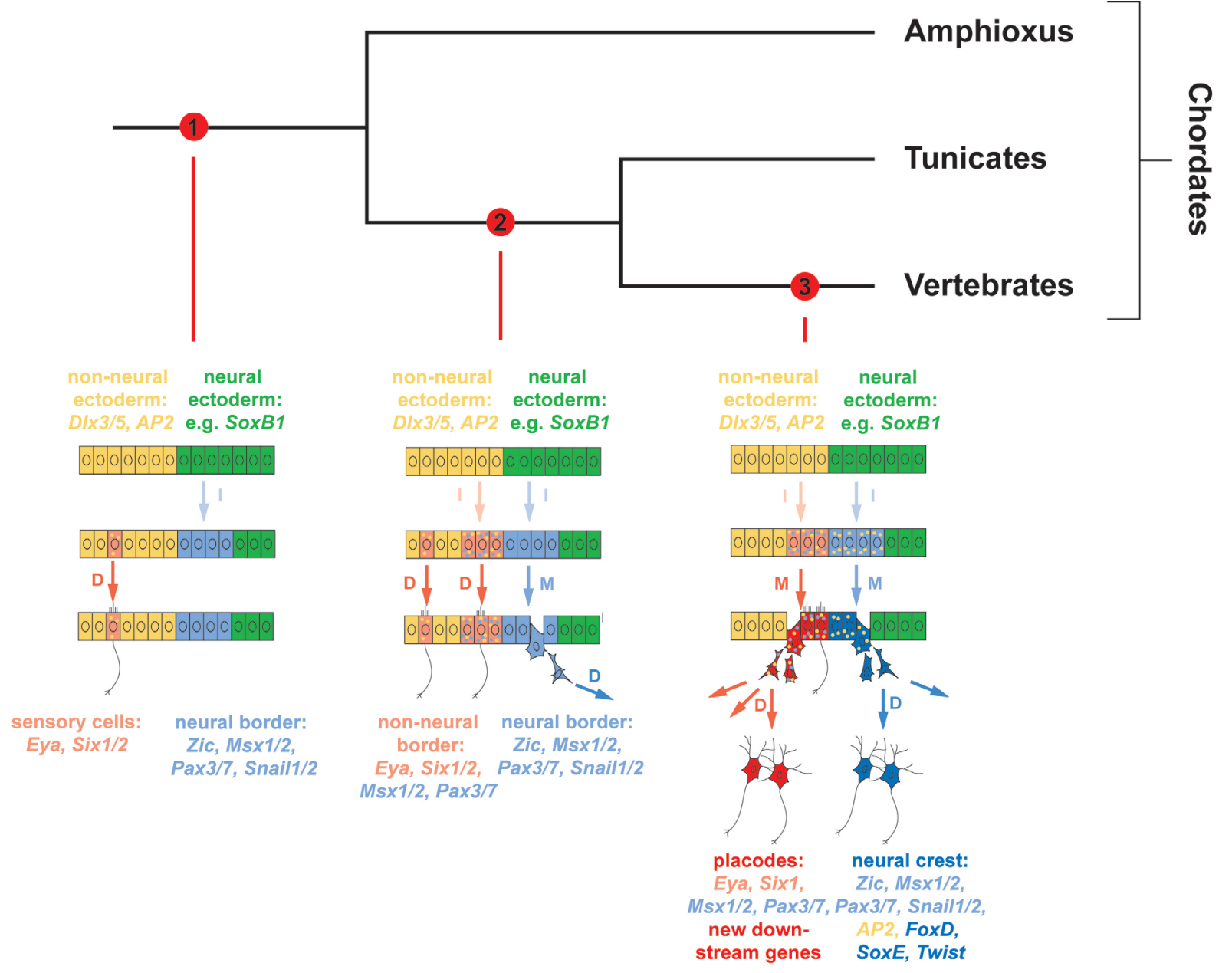

Fig. 6. Scenario for placode evolution in chordates. (1) In the chordate ancestor, Six $1 / 2$ and Eya promoted differentiation of sensory cells scattered throughout non-neural ectoderm (and possibly of neurosecretory cells). (2) In the tunicate-vertebrate ancestor, Six1/2 and Eya were recruited to the dorsalmost non-neural ectoderm, which in conjunction with other TFs gave rise to anterior and posterior proto-placodal ectodermal territories (not shown). Scattered sensory and neurosecretory cells developed from these territories. (3) In the vertebrate lineage, proper placodes evolved, when Six1/2 and Eya adopted a more central role and acquired new downstream genes driving, for example, expansion of sensory progenitors. The neural crest evolved in parallel by GRN rewiring in the lateral neural plate. I, inductive interactions; $M$, migration; $D$, differentiation; $S$, Development of cellular subtypes. Modified from (Schlosser, 2008). 
placodal ectodermal territories then evolved, respectively, into the oral and atrial siphon primordia in tunicates and into an anterior and posterior group of placodes in vertebrates (Schlosser et al., 2014).

However, in tunicates only small populations of sensory cells arise from the ectodermal domain expressing Six1/2 and Eya and many other sensory cells develop from other territories of the non-neural ectoderm (reviewed in (Holland, 2005, Schlosser, 2005, Schlosser, 2015). This suggests first, that in the tunicatevertebrate ancestor as in extant tunicates Six1/2 and Eya were only able in conjunction with other cofactors to specify sensory or neurosecretory cells and, furthermore, that other TFs were able to substitute for Six $1 / 2$ and Eya in some parts of the ectoderm. Only when Six1/2 and Eya adopted a more central role for specification of sensory and neurosecretory cells in the vertebrate ancestor, did their confinement to the anteriormost non-neural ectoderm result in a concentration of sensory and neurosecretory cells in this region. Second, it suggests that in the tunicate-vertebrate ancestor, Six 1/2 and Eya still acted mostly as differentiation genes and that they acquired an additional role in promoting the expansion of sensory and neuronal progenitors only in the vertebrate lineage.

In conclusion, current evidence suggests that proper placodes evolved as evolutionary novelties in the vertebrate lineage by rewiring the GRN both upstream and downstream of Six1/2 TFs, their cofactor Eya and other TFs involved in the regulation of ectodermal patterning and cytodifferentiation. This led to the concentration of pre-existing neurosecretory and sensory cells in dorsal and anterior parts of the non-neural ectoderm as well as the creation of large multicellular sense organs due to the expansion of the sensory and neuronal progenitor pool prior to differentiation. Modification of existing and evolution of novel cell types (e.g. hair cells) followed and placodes diversified into the various types now known in vertebrates. Amphioxus with its isolated sensory cells scattered throughout the ectoderm reminds us - to paraphrase the famous last line of Darwin's Origin (1859) - from how simple a beginning many different placodes "most beautiful and most wonderful have been, and are being, evolved".

\section{References}

ABITUA, P.B., GAINOUS, T.B., KACZMARCZYK, A.N., WINCHELL, C.J., HUDSON, C., KAMATA, K., NAKAGAWA, M., TSUDA, M., KUSAKABE, T.G. and LEVINE, M. (2015). The pre-vertebrate origins of neurogenic placodes. Nature 524: 462-5.

AHRENS, K. and SCHLOSSER, G. (2005). Tissues and signals involved in the induction of placodal Six1 expression in Xenopus laevis Dev.Biol. 288: 40-59.

ALSINA, B., GIRALDEZ, F. and PUJADES, C. (2009). Patterning and cell fate in ear development. Int.J.Dev.Biol. 53 1503-1513.

ARENDT, D., MUSSER, J.M., BAKER, C.V., BERGMAN, A., CEPKO, C., ERWIN, D.H., PAVLICEV, M., SCHLOSSER, G., WIDDER, S., LAUBICHLER, M.D. et al., (2016). The origin and evolution of cell types. Nat Rev Genet 17: 744-757.

ARENDT, D. and NUBLER-JUNG, K. (1994). Inversion of dorsoventral axis? Nature 371: 26-26.

BAATRUP, E. (1981). Primary sensory cells in the skin of amphioxus (Branchiostoma lancelatum). Acta Zool 62: 147-157.

BAATRUP, E. (1982). On the structure of the corpuscles of de Quatrefages (Branchiostoma lanceolatum). Acta Zool. 63: 39-44.

BEASTER-JONES, L., KALTENBACH, S.L., KOOP, D., YUAN, S., CHASTAIN, R. and HOLLAND, L.Z. (2008). Expression of somite segmentation genes in amphioxus: a clock without a wavefront? Dev.Genes Evol. 218: 599-611.

BENITO-GUTIERREZ, E., ILLAS, M., COMELLA, J.X. and GARCIA-FERNANDEZ, J. (2005a). Outlining the nascent nervous system of Branchiostoma floridae (amphioxus) by the pan-neural marker AmphiElav. Brain Res.Bull. 66: 518-521.
BENITO-GUTIERREZ, E., NAKE, C., LLOVERA, M., COMELLA, J.X. and GARCIAFERNANDEZ, J. (2005b). The single AmphiTrk receptor highlights increased complexity of neurotrophin signalling in vertebrates and suggests an early role in developing sensory neuroepidermal cells. Development 132: 2191-2202.

BENITO, J. and PARDOS, F. (1997). Hemichordata. In Microscopic Anatomy of Invertebrates. Vol. 15: Hemichordata, Chaetognatha, and the invertebrate chordates, (ed. HARRISON, F. W. and RUPPERT, E. E.). Wiley-Liss, New York, pp.15-101.

BERTRAND, N., CASTRO, D.S. and GUILLEMOT, F. (2002). Proneural genes and the specification of neural cell types. Nat.Rev.Neurosci. 3: 517-530.

BERTRAND, S., CAMASSES, A., SOMORJAI, I., BELGACEM, M.R., CHABROL, O., ESCANDE, M.L., PONTAROTTI, P. and ESCRIVA, H. (2011). Amphioxus FGF signaling predicts the acquisition of vertebrate morphological traits. Proc.Natl. Acad.Sci.U.S.A 108: 9160-9165

BERTRAND, S. and ESCRIVA, H. (2011). Evolutionary crossroads in developmental biology: amphioxus. Development 138: 4819-4830.

BHAT, N., KWON, H.J. and RILEY, B.B. (2012). A gene network that coordinates preplacodal competence and neural crest specification in zebrafish. Dev Biol.

BLUM, M., FEISTEL, K., THUMBERGER, T. and SCHWEICKERT, A. (2014). The evolution and conservation of left-right patterning mechanisms. Development 141: 1603-13.

BOORMAN, C.J. and SHIMELD, S.M. (2002). Pitx homeobox genes in Ciona and amphioxus show left-right asymmetry is a conserved chordate character and define the ascidian adenohypophysis Evol.Dev. 4: 354-365.

BROOKE, N.M., GARCIA-FERNANDEZ, J. and HOLLAND, P.W.H. (1998). The ParaHox cluster is an evolutionary sister of the Hox gene cluster. Nature 392: 920-922.

CAMPBELL, R.K., SATOH, N. and DEGNAN, B.M. (2004). Piecing together evolution of the vertebrate endocrine system. Trends Genet. 20: 359-366.

CANDIANI, S., HOLLAND, N.D., OLIVERI, D., PARODI, M. and PESTARINO, M. (2008). Expression of the amphioxus Pit-1 gene (AmphiPOU1F1/Pit-1) exclusively in the developing preoral organ, a putative homolog of the vertebrate adenohypophysis. Brain Res.Bull. 75: 324-330.

CANDIANI, S., OLIVERI, D., PARODI, M., BERTINI, E. and PESTARINO, M. (2006) Expression of AmphiPOU-IV in the developing neural tube and epidermal sensory neural precursors in amphioxus supports a conserved role of class IV POU genes in the sensory cells development. Dev.Genes Evol. 216: 623-633.

CASTRO, A., BECERRA, M., MANSO, M.J., SHERWOOD, N.M. and ANADON, R (2006a). Anatomy of the Hesse photoreceptor cell axonal system in the central nervous system of amphioxus. J.Comp Neurol. 494: 54-62.

CASTRO, A., MANSO, M.J. and ANADON, R. (2003). Distribution of neuropeptide $Y$ immunoreactivity in the central and peripheral nervous systems of amphioxus (Branchiostoma lanceolatum Pallas). J.Comp Neurol. 461: 350-361.

CASTRO, L.F., RASMUSSEN, S.L., HOLLAND, P.W., HOLLAND, N.D. and HOLLAND, L.Z. (2006b). A Gbx homeobox gene in amphioxus: Insights into ancestry of the ANTP class and evolution of the midbrain/hindbrain boundary. Dev.Biol. 295:40-51.

CHANG, C.Y., LIU, Y.X., ZHU, Y. and ZHU, H. (1984). The reproductive endocrinology of amphioxus. In Frontiers in physiological research, (ed. CARLICK, D. G. and KORNER, P. I.). Cambridge Univ. Press, Cambridge, pp.79-86.

CHENG, L., ARATA, A., MIZUGUCHI, R., QIAN, Y., KARUNARATNE, A., GRAY, P.A., ARATA, S., SHIRASAWA, S., BOUCHARD, M., LUO, P. et al., (2004). TIx3 and TIx1 are post-mitotic selector genes determining glutamatergic over GABAergic cell fates. Nat Neurosci 7: 510-517.

CHRISTIAEN, L., BOURRAT, F. and JOLY, J.S. (2005). A modular cis-regulatory system controls isoform-specific pitx expression in ascidian stomodaeum. Dev Biol. 277: 557-566.

CHURCHER, A.M. and TAYLOR, J.S. (2009). Amphioxus (Branchiostoma floridae) has orthologs of vertebrate odorant receptors. BMC.Evol.Biol. 9: 242.

DAVIS, S.W., ELLSWORTH, B.S., PEREZ MILLAN, M.I., GERGICS, P., SCHADE, V., FOYOUZI, N., BRINKMEIER, M.L., MORTENSEN, A.H. and CAMPER, S.A. (2013). Pituitary gland development and disease: from stem cell to hormone production. Curr Top Dev Biol 106: 1-47.

DE ROBERTIS, E.M. and SASAI, Y. (1996). A common plan for dorsoventral patterning in Bilateria. Nature 380: 37-40.

DEHAL, P., SATOU, Y., CAMPBELL, R.K., CHAPMAN, J., DEGNAN, B., DE TOMASO, A., DAVIDSON, B., DI GREGORIO, A., GELPKE, M., GOODSTEIN, D.M. et al., (2002). The draft genome of Ciona intestinalis: insights into chordate and vertebrate origins. Science 298: 2157-2167. 
DELSUC, F., BRINKMANN, H., CHOURROUT, D. and PHILIPPE, H. (2006). Tunicates and not cephalochordates are the closest living relatives of vertebrates. Nature 439: 965-968.

DOS SANTOS, S., BARDET, C., BERTRAND, S., ESCRIVA, H., HABERT, D. and QUERAT, B. (2009). Distinct expression patterns of glycoprotein hormone-alpha2 and -beta5 in a basal chordate suggest independent developmental functions. Endocrinology 150: 3815-3822.

DUBOC, V., ROTTINGER, E., LAPRAZ, F., BESNARDEAU, L. and LEPAGE, T. (2005). Left-right asymmetry in the sea urchin embryo is regulated by nodal signaling on the right side. Dev Cell 9: 147-58.

ELSAESSER, R. and PAYSAN, J. (2007). The sense of smell, its signalling pathways, and the dichotomy of cilia and microvilli in olfactory sensory cells. BMC Neurosci 8 Suppl 3: S1.

ESCRIVA, H., HOLLAND, N.D., GRONEMEYER, H., LAUDET, V. and HOLLAND, L.Z. (2002). The retinoic acid signaling pathway regulates anterior/posterior patterning in the nerve cord and pharynx of amphioxus, a chordate lacking neural crest. Development 129: 2905-2916.

FANG, Y.Q., HUANG, W.Q., CHEN, L. and ZHANG, J.S. (1999). Distribution of gonadotropin-releasing hormone in the brain and Hatschek's pit of amphioxus (Branchiostoma belcheri). Acta Zool Sinica 45: 106-111.

FRITZSCH, B., BEISEL, K.W., PAULEY, S. and SOUKUP, G. (2007). Molecular evolution of the vertebrate mechanosensory cell and ear. Int.J.Dev.Biol. 51: 663-678.

GARAFFO, G., CONTE, D., PROVERO, P., TOMAIUOLO, D., LUO, Z., PINCIROLI, P., PEANO, C., D'ATRI, I., GITTON, Y., ETZION, T. et al., (2015). The DIx5 and Foxg1 transcription factors, linked via miRNA-9 and -200 , are required for the development of the olfactory and GnRH system. Mol Cell Neurosci 68: 103-119.

GIVENS, M.L., RAVE-HAREL, N., GOONEWARDENA, V.D., KUROTANI, R., BERDY, S.E., SWAN, C.H., RUBENSTEIN, J.L., ROBERT, B. and MELLON, P.L. (2005). Developmental regulation of gonadotropin-releasing hormone gene expression by the MSX and DLX homeodomain protein families. J.Biol.Chem. 280: 19156-19165.

GLARDON, S., HOLLAND, L.Z., GEHRING, W.J. and HOLLAND, N.D. (1998). Isolation and developmental expression of the amphioxus pax-6 gene (amphipax-6): insights into eye and photoreceptor evolution. Development 125: 2701-2710.

GOODRICH, E.S. (1917). "Proboscis pores" in craniate vertebrates, a suggestion concerning the premandibular somites nad hypophysis. Quart.J.Microsc.Sci. 62: 539-553.

GORBMAN, A. (1983). Early development of the hagfish pituitary gland: evidence for the endodermal origin of the adenohypophysis. Amer.Zool. 23: 639-654.

GORBMAN, A. (1995). Olfactory origins and evolution of the brain-pituitary endocrine system: facts and speculation. Gen.Comp Endocrinol. 97: 171-178.

GORBMAN, A., NOZAKI, M. and KUBOKAWA, K. (1999). A brain-Hatschek's pit connection in amphioxus. Gen.comp.Endocrinol. 113: 251-254.

GOSTLING, N.J. and SHIMELD, S.M. (2003). Protochordate Zic genes define primitive somite compartments and highlight molecular changes underlying neural crest evolution. Evol Dev 5: 136-144.

GRANDE, C. and PATEL, N.H. (2009a). Lophotrochozoa get into the game: the nodal pathway and left/right asymmetry in bilateria. Cold Spring Harb.Symp. Quant.Biol. 74: 281-287.

GRANDE, C. and PATEL, N.H. (2009b). Nodal signalling is involved in left-right asymmetry in snails. Nature 457: 1007-1011.

GROCOTT, T., TAMBALO, M. and STREIT, A. (2012). The peripheral sensory nervous system in the vertebrate head: a gene regulatory perspective. Dev Biol. 370: 3-23.

HATSCHEK, B. (1884). Mittheilungen ueber Amphioxus. Zool.Anz. 7: 517-520.

HOLLAND, L.Z. (2002). Heads or tails? Amphioxus and the evolution of anteriorposterior patterning in deuterostomes. Dev.Biol. 241: 209-228.

HOLLAND, L.Z. (2005). Non-neural ectoderm is really neural: evolution of developmental patterning mechanisms in the non-neural ectoderm of chordates and the problem of sensory cell homologies. J.Exp.Zoolog. 304B: 304-323.

HOLLAND, L.Z. (2009). Chordate roots of the vertebrate nervous system: expanding the molecular toolkit. Nat.Rev.Neurosci. 10: 736-746.

HOLLAND, L.Z. (2014). Genomics, evolution and development of amphioxus and tunicates: The goldilocks principle. J.Exp.Zool. 324: 342-352.

HOLLAND, L.Z., ALBALAT, R., AZUMI, K., BENITO-GUTIERREZ, E., BLOW, M.J., BRONNER-FRASER, M., BRUNET, F., BUTTS, T., CANDIANI, S., DISHAW, L.J. et al., (2008). The amphioxus genome illuminates vertebrate origins and cephalochordate biology. Genome Res. 18: 1100-1111.

HOLLAND, L.Z. and HOLLAND, N.D. (2001). Evolution of neural crest and placodes: amphioxus as a model for the ancestral vertebrate? J.Anat. 199: 85-98.

HOLLAND, L.Z., SCHUBERT, M., HOLLAND, N.D. and NEUMAN, T. (2000). Evolutionary conservation of the presumptive neural plate markers AmphiSox $1 / 2 / 3$ and AmphiNeurogenin in the invertebrate chordate amphioxus. Dev.Biol. 226: 18-33.

HOLLAND, L.Z., SCHUBERT, M., KOZMIK, Z. and HOLLAND, N.D. (1999). AmphiPax3/7, an amphioxus paired box gene: insights into chordate myogenesis, neurogenesis, and the possible evolutionary precursor of definitive vertebrate neural crest. Evol.Dev. 1: 153-165.

HOLLAND, N.D., PANGANIBAN, G., HENYEY, E.L. and HOLLAND, L.Z. (1996). Sequence and developmental expression of AmphiDIl, an amphioxus distalless gene trabscribed in the ectoderm, epidermis and nervous system: insights into evolution of craniate forebrain and neural crest. Development 122: 2911-2920.

HOLLAND, N.D., PARIS, M. and KOOP, D. (2009). The club-shaped gland of amphioxus: export of secretion to the pharynx in pre-metamorphic larvae and apoptosis during metamorphosis. Acta Zoologica 90: 372-379.

HUANG, C., CHAN, J.A. and SCHUURMANS, C. (2014). Proneural bHLH genes in development and disease. Curr Top Dev Biol 110: 75-127.

HUISING, M.O., KRUISWIJK, C.P. and FLIK, G. (2006). Phylogeny and evolution of class-I helical cytokines. J Endocrinol 189: 1-25.

IRIMIA, M., PINEIRO, C., MAESO, I., GOMEZ-SKARMETA, J.L., CASARES, F. and GARCIA-FERNANDEZ, J. (2010). Conserved developmental expression of Fezf in chordates and Drosophila and the origin of the Zona Limitans Intrathalamica (ZLI) brain organizer. Evodevo 1: 7.

JACKMAN, W.R., LANGELAND, J.A. and KIMMEL, C.B. (2000). islet reveals segmentation in the amphioxus hindbrain homolog. Dev.Biol. 220: 16-26.

KAJI, T., AIZAWA, S., UEMURA, M. and YASUI, K. (2001). Establishment of left-right asymmetric innervation in the lancelet oral region. J.Comp.Neurol. 435: 394-405.

KAJI, T., REIMER, J.D., MOROV, A.R., KURATANI, S. and YASUI, K. (2016). Amphioxus mouth after dorso-ventral inversion. Zoological Lett 2: 2.

KALTENBACH, S.L., HOLLAND, L.Z., HOLLAND, N.D. and KOOP, D. (2009a). Developmental expression of the three iroquois genes of amphioxus (BflrxA, BflrxB, and $\mathrm{Bf} \mid \mathrm{rxC}$ ) with special attention to the gastrula organizer and anteroposterior boundaries in the central nervous system. Gene Expr.Patterns. 9: 329-334.

KALTENBACH, S.L., YU, J.K. and HOLLAND, N.D. (2009b). The origin and migration of the earliest-developing sensory neurons in the peripheral nervous system of amphioxus. Evol.Dev. 11: 142-151.

KAUPP, U.B. (2010). Olfactory signalling in vertebrates and insects: differences and commonalities. Nat Rev Neurosci 11: 188-200.

KAWAUCHI, H. and SOWER, S.A. (2006). The dawn and evolution of hormones in the adenohypophysis. Gen.Comp Endocrinol. 148: 3-14.

KELBERMAN, D., RIZZOTI, K., LOVELL-BADGE, R., ROBINSON, I.C. and DATTANI, M.T. (2009). Genetic regulation of pituitary gland development in human and mouse. Endocr.Rev. 30: 790-829.

KOOP, D., CHEN, J., THEOdOSIOU, M., CARVALHO, J.E., ALVAREZ, S., DE LERA, A.R., HOLLAND, L.Z. and SCHUBERT, M. (2014). Roles of retinoic acid and Tbx1/10 in pharyngeal segmentation: amphioxus and the ancestral chordate condition. Evodevo 5: 36.

KOOP, D., HOLLAND, N.D., SEMON, M., ALVAREZ, S., DE LERA, A.R., LAUDET, V., HOLLAND, L.Z. and SCHUBERT, M. (2010). Retinoic acid signaling targets Hox genes during the amphioxus gastrula stage: insights into early anterior-posterior patterning of the chordate body plan. Dev Biol. 338: 98-106.

KOZMIK, Z., HOLLAND, N.D., KALOUSOVA, A., PACES, J., SCHUBERT, M. and HOLLAND, L.Z. (1999). Characterization of an amphioxus paired box gene, AmphiPax2/5/8: developmental expression patterns in optic support cells, nephridium, thyroid-like structures and pharyngeal gill slits, but not in the midbrain-hindbrain boundary region. Development 126: 1295-1304.

KOZMIK, Z., HOLLAND, N.D., KRESLOVA, J., OLIVERI, D., SCHUBERT, M., JONASOVA, K., HOLLAND, L.Z., PESTARINO, M., BENES, V. and CANDIANI, S. (2007) Pax-Six-Eya-Dach network during amphioxus development: conservation in vitro but context-specificity in vivo Dev.Biol. 306: 143-159.

KOZMIKOVA, I., CANDIANI, S., FABIAN, P., GURSKA, D. and KOZMIK, Z. (2013). Essential role of Bmp signaling and its positive feedback loop in the early cell fate evolution of chordates. Dev Biol. 382: 538-554. 
KURATANI, S. and ADACHI, N. (2016). What are Head Cavities? - A History of Studies on Vertebrate Head Segmentation. Zoolog Sci 33: 213-28.

KWON, H.J., BHAT, N., SWEET, E.M., CORNELL, R.A. and RILEY, B.B. (2010). Identification of early requirements for preplacodal ectoderm and sensory organ development. PLoS.Genet. 6.

LACALLI, T. (2007). Mucus secretion and transport in amphioxus larvae: organisation and ultrastructure of the food trapping system, and implications for head evolution. Acta zool.(Stockholm) 89: 219-230.

LACALLI, T.C. (2002). Sensory pathways in amphioxus larvae. I. Constituent fibers of the rostral and anterodorsal nerves, their targets and evolutionary significance. Acta Zool 83: 149-166.

LACALLI, T.C. (2004). Sensory systems in amphioxus: a window on the ancestral chordate condition. Brain Behav.Evol 64: 148-162.

LACALLI, T.C., GILMOUR, T.H.J. and KELLY, S.J. (1999). The oral nerve plexus in amphioxus larvae: function, cell types and phylogenetic significance. Proc.R.Soc. Lond.B 266: 1461-1470.

LACALLI, T.C. and HOU, S. (1999). A reexamination of the epithelial sensory cells of amphioxus (Branchiostoma) Acta zool.(Stockkolm) 80: 125-134.

LANGELAND, J.A., TOMSA, J.M., JACKMAN, W.R. and KIMMEL, C.B. (1998). An amphioxus snail gene: Expression in paraxial mesoderm and neural plate suggests a conserved role in patterning the chordate embryo. Dev.Genes Evol.208:569-577.

LE PETILLON, Y., OULION, S., ESCANDE, M.L., ESCRIVA, H. and BERTRAND, S. (2013). Identification and expression analysis of BMP signaling inhibitors genes of the DAN family in amphioxus. Gene Expr.Patterns. 13: 377-383.

LEMAIRE, P. (2009). Unfolding a chordate developmental program, one cell at a time: invariant cell lineages, short-range inductions and evolutionary plasticity in ascidians. Dev.Biol. 332: 48-60.

LI, M., GAO, Z., JI, D. and ZHANG, S. (2014). Functional characterization of GHlike homolog in amphioxus reveals an ancient origin of $\mathrm{GH} / \mathrm{GH}$ receptor system. Endocrinology 155: 4818-30.

LITSIOU, A., HANSON, S. and STREIT, A. (2005). A balance of FGF, BMP and WNT signalling positions the future placode territory in the head. Development 132: 4051-4062.

LOGAN, C., WINGATE, R.J., MCKAY, I.J. and LUMSDEN, A. (1998). TIx-1 and TIX-3 homeobox gene expression in cranial sensory ganglia and hindbrain of the chick embryo: markers of patterned connectivity. J.Neurosci. 18: 5389-402.

LOWE, C.J., TERASAKI, M., WU, M., FREEMAN, R.M., JR., RUNFT, L., KWAN, K., HAIGO, S., ARONOWICZ, J., LANDER, E., GRUBER, C. et al., (2006). Dorsoventral patterning in hemichordates: insights into early chordate evolution. PLoS.Biol. 4: 1602-1619.

LU, T.M., LUO, Y.J. and YU, J.K. (2012). BMP and Delta/Notch signaling control the development of amphioxus epidermal sensory neurons: insights into the evolution of the peripheral sensory system. Development 139: 2020-2030.

MAIER, E.C., SAXENA, A., ALSINA, B., BRONNER, M.E. and WHITFIELD, T.T. (2014). Sensational placodes: Neurogenesis in the otic and olfactory systems. Dev Biol. 389: 50-67.

MASSARI, M., CANDIANI, S. and PESTARINO, M. (1999). Distribution and localization of immunoreactive FMRFamide-like peptides in the lancelet. Eur.J.Histochem. 43: 63-69.

MAZET, F., HUTT, J.A., MILLOZ, J., MILLARD, J., GRAHAM, A. and SHIMELD, S.M. (2005). Molecular evidence from Ciona intestinalis for the evolutionary origin of vertebrate sensory placodes. Dev.Biol. 282: 494-508.

MAZET, F., MASOOD, S., LUKE, G.N., HOLLAND, N.D. and SHIMELD, S.M. (2004). Expression of AmphiCoe, an amphioxus COE/EBF gene, in the developing central nervous system and epidermal sensory neurons. Genesis. 38: 58-65.

MEULEMANS, D. and BRONNER-FRASER, M. (2002). Amphioxus and lamprey AP-2 genes: implications for neural crest evolution and migration patterns. Development 129: 4953-4962.

MEULEMANS, D. and BRONNER-FRASER, M. (2004). Gene-regulatory interactions in neural crest evolution and development. Dev.Cell 7: 291-299.

MEULEMANS, D. and BRONNER-FRASER, M. (2007). The amphioxus SoxB family: implications for the evolution of vertebrate placodes. Int.J.Biol.Sci. 3: 356-364.

MEULEMANS, D., MCCAULEY, D. and BRONNER-FRASER, M. (2003). Id expression in amphioxus and lamprey highlights the role of gene cooption during neural crest evolution. Dev Biol. 264: 430-442.
MINARIK M., STUNDL J., FABIAN P., JANDZIK D., METSCHER B.D., PSENICKA M., GELA D., OSORIO-PÉREZ A., ARIAS-RODRIGUEZ L., HORÁCEK I. and CERNY R. (2017). Preoral gut contributes to facial structures in non-teleost fishes. Nature 547: 209-212.

MINGUILLON, C., JIMENEZ-DELGADO, S., PANOPOULOU, G. and GARCIAFERNANDEZ, J. (2003). The amphioxus Hairy family: differential fate after duplication. Development 130: 5903-5914.

MIRABEAU, O. and JOLY, J.S. (2013). Molecular evolution of peptidergic signaling systems in bilaterians. Proc.Natl.Acad.Sci. USA 110: E2028-E2037.

MOLINA, M.D., DE CROZE, N., HAILLOT, E. and LEPAGE, T. (2013). Nodal: master and commander of the dorsal-ventral and left-right axes in the sea urchin embryo. Curr Opin Genet Dev 23: 445-53.

NIIMURA, Y. (2009). Evolutionary dynamics of olfactory receptor genes in chordates: interaction between environments and genomic contents. Hum Genomics 4: 107-18.

NORTHCUTT, R.G. (2004). Taste buds: development and evolution. Brain Behav. Evol 64: 198-206.

NORTHCUTT, R.G. and GANS, C. (1983). The genesis of neural crest and epidermal placodes: a reinterpretation of vertebrate origins. Q.Rev.Biol. 58: 1-28.

NOZAKI, M. (2008). The hagfish pituitary gland and its putative adenohypophysial hormones. Zoolog Sci 25: 1028-1036.

NOZAKI, M. and GORBMAN, A. (1992). The question of functional homology of Hatschek's pit of amphioxus (Branchiostoma belcheri) and the vertebrate adenohypophysis. Zool.Sci. 9: 387-395

OISI, Y., OTA, K.G., KURAKU, S., FUJIMOTO, S. and KURATANI, S. (2013). Craniofacial development of hagfishes and the evolution of vertebrates. Nature 493: 175-180.

ONAI, T., LIN, H.C., SCHUBERT, M., KOOP, D., OSBORNE, P.W., ALVAREZ, S. ALVAREZ, R., HOLLAND, N.D. and HOLLAND, L.Z. (2009). Retinoic acid and Wnt/ beta-catenin have complementary roles in anterior/posterior patterning embryos of the basal chordate amphioxus. Dev Biol 332: 223-33.

ONAI, T., YU, J.K., BLITZ, I.L., CHO, K.W. and HOLLAND, L.Z. (2010). Opposing Nodal/Vg1 and BMP signals mediate axial patterning in embryos of the basal chordate amphioxus. Dev Biol. 344: 377-389.

OSUGI, T., SON, Y.L., UBUKA, T., SATAKE, H. and TSUTSUI, K. (2016). RFamide peptides in agnathans and basal chordates. Gen Comp Endocrinol 227: 94-100.

PASCUAL-ANAYA, J., ADACHI, N., ALVAREZ, S., KURATANI, S., D'ANIELLO, S. and GARCIA-FERNANDEZ, J. (2012). Broken colinearity of the amphioxus Hox cluster. Evodevo. 3: 28.

PATTHEY, C., SCHLOSSER, G. and SHIMELD, S.M. (2014). The evolutionary history of vertebrate cranial placodes--I: cell type evolution. Dev Biol 389: 82-97.

PETER, I.S. and DAVIDSON, E.H. (2015). Genomic control process: Development and evolution. Elsevier, Amsterdam.

PETERSON, K.J., ARENAS-MENA, C. and DAVIDSON, E.H. (2000). The A/P axis in echinoderm ontogeny and evolution: evidence from fossils and molecules. Evol.Dev. 2: 93-101.

PIEPER, M., AHRENS, K., RINK, E., PETER, A. and SCHLOSSER, G. (2012). Differential distribution of competence for panplacodal and neural crest induction to non-neural and neural ectoderm. Development 139: 1175-1187.

PUTNAM, N.H., BUTTS, T., FERRIER, D.E., FURLONG, R.F., HELLSTEN, U., KAWASHIMA, T., ROBINSON-RECHAVI, M., SHOGUCHI, E., TERRY, A., YU, J.K. et al., (2008). The amphioxus genome and the evolution of the chordate karyotype. Nature 453: 1064-1071.

RASMUSSEN, S.L., HOLLAND, L.Z., SCHUBERT, M., BEASTER-JONES, L. and HOLLAND, N.D. (2007). Amphioxus AmphiDelta: evolution of delta protein structure, segmentation, and neurogenesis. Genesis 45: 113-122.

ROCH, G.J. and SHERWOOD, N.M. (2014). Glycoprotein hormones and their receptors emerged at the origin of metazoans. Genome Biol Evol 6: 1466-1479.

ROCH, G.J., TELLO, J.A. and SHERWOOD, N.M. (2014). At the transition from invertebrates to vertebrates, a novel $\mathrm{GnRH}$-like peptide emerges in amphioxus. Mol.Biol.Evol. 31: 765-778.

SAHLIN, K. and OLSSON, R. (1986). The wheel organ and Hatschek's groove in the lancelet, Branchiostoma lanceolatum (cephalochordata). Acta Zool. 67: 201-209.

SAINT-JEANNET, J.P. and MOODY, S.A. (2014). Establishing the pre-placoda region and breaking it into placodes with distinct identities. Dev Biol. 389: 13-27.

SALZET, M., SALZET-RAVEILLON, B., COCQUERELLE, C., VERGER-BOCQUET, M., PRYOR, S.C., RIALAS, C.M., LAURENT, V. and STEFANO, G.B. (1997). 
Leech immunocytes contain proopiomelanocortin: nitric oxide mediates hemolymph proopiomelanocortin processing. J.Immunol. 159: 5400-5411.

SATOH, G. (2005). Characterization of novel GPCR gene coding locus in amphioxus genome: Gene structure, expression, and phylogenetic analysis with implications for its involvement in chemoreception. Genesis. 41: 47-57.

SATOH, G., WANG, Y., ZHANG, P. and SATOH, N. (2001). Early development of amphioxus nervous system with special reference to segmental cell organization and putative sensory cell precursors: a study based on the expression of panneuronal marker gene Hu/elav. J.Exp.Zool. 291: 354-364.

SCHLOSSER, G. (2005). Evolutionary origins of vertebrate placodes: insights from developmental studies and from comparisons with other deuterostomes. J.Exp. Zoolog. 304B: 347-399.

SCHLOSSER, G. (2006). Induction and specification of cranial placodes. Dev.Biol. 294: 303-351.

SCHLOSSER, G. (2008). Do vertebrate neural crest and cranial placodes have a common evolutionary origin? Bioessays 30: 659-672.

SCHLOSSER, G. (2010). Making senses: Development of vertebrate cranial placodes. Int.Rev.Cell Mol.Biol. 283C: 129-234.

SCHLOSSER, G. (2015). Vertebrate cranial placodes as evolutionary innovations--the ancestor's tale. Curr Top Dev Biol 111: 235-300.

SCHLOSSER, G., PATTHEY, C. and SHIMELD, S.M. (2014). The evolutionary history of vertebrate cranial placodes II. Evolution of ectodermal patterning. Dev Biol 389: 98-119.

SCHUBERT, M., ESCRIVA, H., XAVIER-NETO, J. and LAUDET, V. (2006a). Amphioxus and tunicates as evolutionary model systems. Trends Ecol.Evol. 21: 269-277.

SCHUBERT, M., HOLLAND, L.Z., STOKES, M.D. and HOLLAND, N.D. (2001). Three amphioxus Wnt genes (AmphiWnt3, AmphiWnt5, and AmpjWnt6) associated with the tailbud: the evolution of somitogenesis in chordates. Dev.Biol. 240: 262-273.

SCHUBERT, M., HOLLAND, N.D., ESCRIVA, H., HOLLAND, L.Z. and LAUDET, V. (2004). Retinoic acid influences anteroposterior positioning of epidermal sensory neurons and their gene expression in a developing chordate (amphioxus). Proc Natl Acad Sci USA 101: 10320-10325.

SCHUBERT, M., HOLLAND, N.D., LAUDET, V. and HOLLAND, L.Z. (2006b). A retinoic acid-Hox hierarchy controls both anterior/posterior patterning and neuronal specification in the developing central nervous system of the cephalochordate amphioxus. Dev.Biol. 296: 190-202.

SCHULTE, E. and RIEHL, R. (1977). Elektronenmikroskopische Untersuchungen an den Oralcirren und der Haut von Branchiostoma lanceolatum Helgol nd. wiss. Meeresunters. 29: 337-357.

SCHWEICKERT, A., VICK, P., GETWAN, M., WEBER, T., SCHNEIDER, I., EBERHARDT, M., BEYER, T., PACHUR, A. and BLUM, M. (2010). The nodal inhibitor Coco is a critical target of leftward flow in Xenopus. Curr Biol 20: 738-743.

SCHWEICKERT, A., WEBER, T., BEYER, T., VICK, P., BOGUSCH, S., FEISTEL, K. and BLUM, M. (2007). Cilia-driven leftward flow determines laterality in Xenopus. Curr Biol 17: 60-66.

SHARMAN, A.C., SHIMELD, S.M. and HOLLAND, P.W.H. (1999). An amphioxus Msx gene expressed predominantly in the dorsal neural tube. Dev.Genes Evol. 209: 260-263.

SOUKUP, V., EPPERLEIN, H.H., HORACEK, I. and CERNY, R. (2008). Dual epithelial origin of vertebrate oral teeth. Nature 455: 795-798.

SOUKUP, V. and KOZMIK, Z. (2016). Zoology: A New Mouth for Amphioxus. Curr Biol 26: R367-8.

SOUKUP, V., YONG, L.W., LU, T.M., HUANG, S.W., KOZMIK, Z. and YU, J.K. (2015). The Nodal signaling pathway controls left-right asymmetric development in amphioxus. Evodevo 6: 5.

SOWER, S.A., FREAMAT, M. and KAVANAUGH, S.I. (2009). The origins of the vertebrate hypothalamic-pituitary-gonadal (HPG) and hypothalamic-pituitary-thyroid (HPT) endocrine systems: new insights from lampreys. Gen Comp Endocrinol 161: 20-29.

SOWER, S.A., MORIYAMA, S., KASAHARA, M., TAKAHASHI, A., NOZAKI, M., UCHIDA, K., DAHLSTROM, J.M. and KAWAUCHI, H. (2006). Identification of sea lamprey GTHbeta-like cDNA and its evolutionary implications. Gen Comp Endocrinol 148: 22-32.

STACH, T. (2002). Minireview: On the homology of the protocoel in Cephalochordata and 'lower' Deuterostomia. Acta Zoologica 83: 25-31.
STEFANO, G.B., SALZET-RAVEILLON, B. and SALZET, M. (1999). Mytilus edulis hemolymph contains pro-opiomelanocortin: LPS and morphine stimulate differential processing. Brain Res.Mol.Brain Res. 63: 340-350.

STOKES, M.D. and HOLLAND, N.D. (1995). Embryos and larvae of a lancelet, Branchiostoma floridae, from hatching through metamorphosis: growth in the laboratory and external morphology. Acta Zool. 76: 105-120.

STONE, L.M., FINGER, T.E., TAM, P.P. and TAN, S.S. (1995). Taste receptor cells arise from local epithelium, not neurogenic ectoderm. Proc Natl Acad Sci USA 92: 1916-120.

TJOA, L.T. and WELSCH, U. (1974). Electron microscopical observations on Kolliker's and Hatschek's pit and on the wheel organ in the head region of Amphioxus (Branchiostoma lanceolatum). Cell Tissue Res. 153: 175-187.

TORESSON, H., MARTINEZ-BARBERA, J.P., BARDSLEY, A., CAUBIT, X. and KRAUSS, S. (1998). Conservation of BF-1 expression in amphioxus and zebrafish suggests evolutionary ancestry of anterior cell types that contribute to the vertebrate forebrain. Dev.Genes Evol. 208: 431-439.

UCHIDA, K., MORIYAMA, S., CHIBA, H., SHIMOTANI, T., HONDA, K., MIKI, M., TAKAHASHI, A., SOWER, S.A. and NOZAKI, M. (2010). Evolutionary origin of a functional gonadotropin in the pituitary of the most primitive vertebrate, hagfish. Proc.Natl.Acad.Sci.USA 107: 15832-15837.

VAN OtTERLOO, E., LI, W., GARNETT, A., CATTELL, M., MEDEIROS, D.M. and CORNELL, R.A. (2012). Novel Tfap2-mediated control of soxE expression facilitated the evolutionary emergence of the neural crest. Development 139: 720-730.

WADA, H., SAIGA, H., SATOH, N. and HOLLAND, P.W.H. (1998). Tripartite organization of the ancestral chordate brain and the antiquity of placodes: insights from ascidian Pax-2/5/8, Hox and Otx genes. Development 125: 1113-1122.

WANG, Y., ZHANG, P.J., YASUI, K. and SAIGA, H. (2002). Expression of Bblhx3, a LIM-homeobox gene, in the development of amphioxus Branchiostoma belcheri tsingtauense. Mech Dev 117: 315-319.

WELSCH, L.T. and WELSCH, U. (1978). Histologische und elektronenmikroskopische Untersuchungen an der pr,oralen Wimpergrube von Saccoglossus horsti (Hemichordata) und der Hatschekschen Grube von Branchiostoma lanceolatum (Acrania). Ein Beitrag zur phylogenetischen Entwicklung der Adenohypophyse. Zool.Jb.Anat. 100: 564-578.

WILLIAMS, D.K., GANNON-MURAKAMI, L., ROUGON, G. and UDIN, S.B. (1996). Polysialylated neural cell adhesion molecule and plasticity of ipsilateral connections in Xenopus tectum. Neuroscience 70: 277-285.

YASUI, K. and KAJI, T. (2008). The lancelet and ammocoete mouths. Zoolog.Sci. 25: 1012-1019.

YASUI, K., ZHANG, S., UEMURA, M. and SAIGA, H. (2000). Left-right asymmetric expression of BbPtx, a Ptx-related gene, in a lancelet species and the developmental left-sidedness in deuterostomes. Development 127: 187-195.

YASUI, K., ZHANG, S.C., UEMURA, M., AIZAWA, S. and UEKI, T. (1998). Expression of a twist-related gene, Bbtwist, during the development of a lancelet species and its relation to cephalochordate anterior structures. Dev Biol 195: 49-59.

YONG, L.W., BERTRAND, S., YU, J-K., ESCRIVA, H. and HOLLAND, N.D. (2017). Conservation of BMP2/4 expression pattern within the clade Branchiostoma (amphioxus): Resolving interspecific differences. Gene Exp. Patterns 25-26: 71-75.

YOSHIDA, K. and SAIGA, H. (2008). Left-right asymmetric expression of Pitx is regulated by the asymmetric Nodal signaling through an intronic enhancer in Ciona intestinalis. Dev Genes Evol. 218: 353-360.

YOSHIDA, K., UENO, M., NIWANO, T. and SAIGA, H. (2012). Transcription regulatory mechanism of Pitx in the papilla-forming region in the ascidian, Halocynthia roretzi, implies conserved involvement of Otx as the upstream gene in the adhesive organ development of chordates. Dev Growth Differ. 54: 649-659.

YU, J.K., HOLLAND, L.Z. and HOLLAND, N.D. (2002a). An amphioxus nodal gene (AmphiNodal) with early symmetrical expression in the organizer and mesoderm and later asymmetrical expression associated with left-right axis formation. Evol Dev 4: 418-425.

YU, J.K., HOLLAND, L.Z., JAMRICH, M., BLITZ, I.L. and HOLLAN, N.D. (2002b). AmphiFoxE4, an amphioxus winged helix/forkhead gene encoding a protein closely related to vertebrate thyroid transcription factor-2: expression during pharyngeal development. Evol.Dev. 4: 9-15.

YU, J.K., HOLLAND, N.D. and HOLLAND, L.Z. (2002c). An amphioxus winged helix/ forkhead gene, AmphiFoxD: insights into vertebrate neural crest evolution. Dev Dyn 225: 289-297. 
YU, J.K., HOLLAND, N.D. and HOLLAND, L.Z. (2003). AmphiFoxQ2, a novel winged helix/forkhead gene, exclusively marks the anterior end of the amphioxus embryo. Dev Genes Evol 213: 102-105.

YU, J.K., MEULEMANS, D., MCKEOWN, S.J. and BRONNER-FRASER, M. (2008). Insights from the amphioxus genome on the origin of vertebrate neural crest. Genome Res. 18: 1127-1132.
YU, J.K., SATOU, Y., HOLLAND, N.D., SHIN, I., KOHARA, Y., SATOH, N., BRONNERFRASER, M. and HOLLAND, L.Z. (2007). Axial patterning in cephalochordates and the evolution of the organizer. Nature 445: 613-617.

ZHANG, Y. and MAO, B. (2009). Developmental expression of an amphioxus (Branchiostoma belcheri) gene encoding a GATA transcription factor. Zoological Research 30: 137-143. 


\section{Further Related Reading, published previously in the Int. J. Dev. Biol.}

From the American to the European amphioxus: towards experimental Evo-Devo at the origin of chordates

Jordi Garcia-Fernàndez, Senda Jiménez-Delgado, Juan Pascual-Anaya, Ignacio Maeso, Manuel Irimia, Carolina Minguillón, Èlia BenitoGutiérrez, Josep Gardenyes, Stéphanie Bertrand and Salvatore D’Aniello

Int. J. Dev. Biol. (2009) 53: 1359-1366

https://doi.org/10.1387/ijdb.072436jg

Evolution of CUT class homeobox genes: insights from the genome of the amphioxus, Branchiostoma floridae Naohito Takatori and Hidetoshi Saiga

Int. J. Dev. Biol. (2008) 52: 969-977

https://doi.org/10.1387/ijdb.072541nt

Peter Holland, homeobox genes and the developmental basis of animal diversity

Sebastian M. Shimeld

Int. J. Dev. Biol. (2008) 52: 3-7

https://doi.org/10.1387/ijdb.072394ss

Developmental expression of the High Mobility Group B gene in the amphioxus, Branchiostoma belcheri tsingtauense

Xiangwei Huang, Lifeng Wang and Hongwei Zhang

Int. J. Dev. Biol. (2005) 49: 49-46

http://www.intjdevbiol.com/web/paper/041915xh

Cell morphology in amphioxus nerve cord may reflect the time course of cell differentiation T C Lacalli

Int. J. Dev. Biol. (2000) 44: 903-906

http://www.intjdevbiol.com/web/paper/11206331

Embryonic development of heads, skeletons and amphioxus: Edwin S. Goodrich revisited P W Holland

Int. J. Dev. Biol. (2000) 44: 29-34

http://www.intjdevbiol.com/web/paper/10761843

Amphioxus Hox genes: insights into evolution and development

$\mathrm{J}$ Garcia-Fernàndez and $\mathrm{P}$ W Holland

Int. J. Dev. Biol. (1996) 40: S71-S72

http://www.intjdevbiol.com/web/paper/9087701

5 yr ISI Impact Factor $(2013)=2.879$
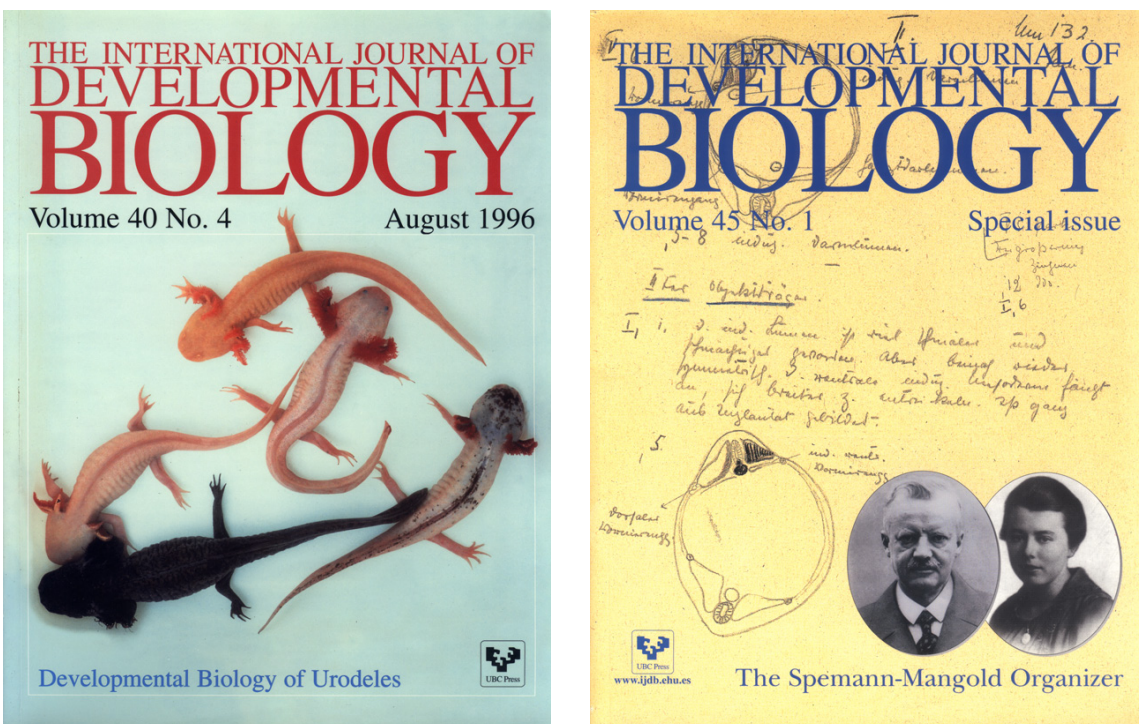

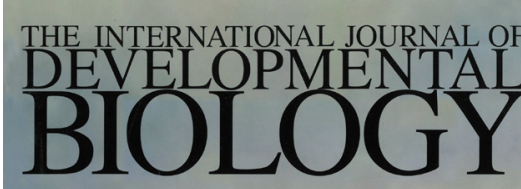

Volume 47 Nos. $7 / 8$ Special Issue

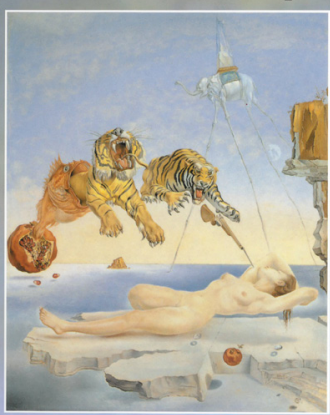

Evolution \& Development ind

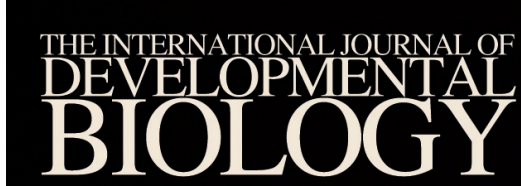

Volume 61 Nos. 10/11/12 Special Issue

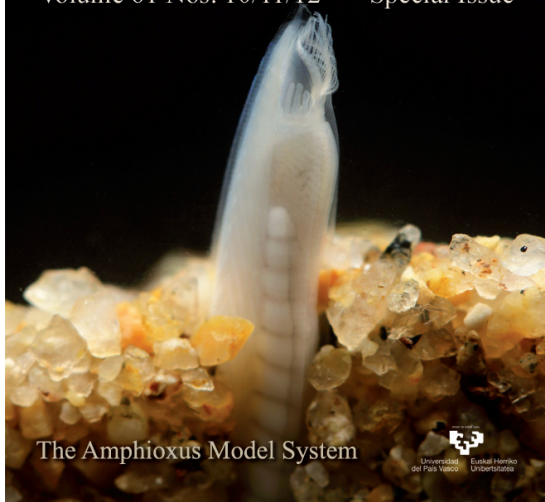

